\title{
Planning for a Different Kind of Sea Change: Lessons from Australia for Sea Level Rise and Coastal Flooding
}

Ayşın Dedekorkut-Howes (The first and the corresponding author)

School of Environment and Science \& Cities Research Institute, Griffith University, Gold Coast, Australia. https://orcid.org/0000-0002-3844-4796, a.dedekorkut@griffith.edu.au

\section{Elnaz Torabi}

School of Environment and Science \& Cities Research Institute, Griffith University, Gold Coast, Australia. https://orcid.org/0000-0003-4578-8199, e.torabi@griffith.edu.au

\section{Michael Howes}

School of Environment and Science \& Cities Research Institute, Griffith University, Gold Coast, Australia. https://orcid.org/0000-0003-1102-1483, m.howes@griffith.edu.au

\begin{abstract}
Climate change increases hazards for coastal cities where a large proportion of the world's population lives. Adaptation to its impacts ought to be a key focus for planning and policy-making in highly vulnerable countries like Australia. This responsibility, however, has been largely left to local councils with mixed results. This leaves substantial parts of the population at risk where adaptation plans are lacking. Even worse, since the impacts of climate change do not respect jurisdictional boundaries, there is a spill-over risk where good adaptation planning by one council may be undermined by the lack of action in an adjacent council. These risks can be reduced if state and federal governments provide more consistent support and guidance. This paper takes an integrated approach in comparing the relevant legislation, policies, plans, and strategies related to coastal management across the national and state/territory jurisdictions in Australia. The findings indicate that there are major differences, with some states (South Australia, Victoria, Western Australia, and Queensland) having more detailed policies and plans for addressing sea level rise and coastal flooding. The findings have implications beyond Australia, particularly for those
\end{abstract}


countries with more devolved or federal systems of government, and provide key lessons for adaptation to climate change.

\section{Key policy insights:}

- In the absence of national guidance and leadership, climate adaptation responses will remain uneven across jurisdictions placing more of the population at risk and undermining what adaptation plans there are.

- National, state and territory policies or plans are more effective if they are consistent over time, but they are undermined by reversals when governments change between political parties that have widely varying views on climate change.

- Effective long-term adaptation policymaking and planning therefore require a bipartisan commitment and consistent political will across the major political parties to prioritise the problem and commit significant public resources to a response.

Keywords: Climate change adaptation; Protect, Accommodate, Retreat; Structural and non-structural measures; Policy reversal; Horizontal and vertical consistency; Policy review

\section{Introduction}

While rising temperatures have been the focus of the media coverage of climate change, other impacts are of major concern for coastal cities (Intergovernmental Panel on Climate Change [IPCC] 2014). Sea level rise (SLR) and storm surges will significantly increase the risk of flooding in low-lying coastal areas (UN-Habitat 2013). Australia is highly vulnerable with $85 \%$ of its population living in coastal areas (see Figure 1) (Department of Climate Change [DCC] 2009). The IPCC's $5^{\text {th }}$ Assessment Report pinpoints SLR as a significant risk for Australia due to its "intensifying coastal development and the location of population centers and infrastructure" (Reisinger et al. 2014: 1384). One national assessment identified more than AU\$226 billion (2008 replacement value) of commercial, industrial, road, rail, and residential assets at risk from a SLR of 1.1m (DCCEE 2011a). This includes up to 274,000 residential, 8,600 
commercial, 6,200 light industrial buildings, and 35,000 km of roads and rail. A recent analysis found that, if drastic actions to address the risk of extreme weather events and climate change are not undertaken immediately, the number of uninsurable addresses in Australia is projected to double (nearly 1 in 20) by 2100 (Ting et al. 2019). The majority of these are in the most populated urban areas, with the state of Queensland being the most vulnerable to the dual threats of riverine flooding and coastal inundation, set to rise dramatically post-2060. How prepared is Australia to manage these challenges and what can we learn from its experience to date? These questions lie at the heart of this paper.

[Insert Figure 1 about here]

Various studies have examined Australia's response to SLR and coastal flooding (e.g. Bradley et al. 2015, Harvey et al. 2012a, Kellet et al. 2012, Warnken and Mosadeghi 2018); however, none have evaluated coastal adaptation systematically and holistically by analysing all policies related to development, planning, infrastructure, and climate change adaptation. Government reports that have audited climate change adaptation have either investigated adaptation in general without focusing on coastal areas (Productivity Commission 2012), or considered only coastal policies (Clarke 2010). The only report that has comprehensively reviewed policies related to climate change, coastal management, statutory planning, and emergency responses dates back to 2011 (Gibbs and Hill 2011), when the commitment to climate change had peaked across the country, only to decline after the election of conservative governments at all levels (Dedekorkut-Howes and Howes 2014, Howes and Dedekorkut-Howes 2016). It is therefore important to review current policies and plans to see how well the national and state governments are guiding and supporting local governments to develop their responses to SLR and coastal flooding, especially since the levels of risk have recently increased (IPCC 2018). We do this by first describing the context of climate adaptation in Australia, in particular coastal climate adaptation. After describing our methods, we provide a brief overview of the main coastal climate adaptation strategies and policies at 
national and state/territory levels. We conclude with a discussion of our findings and their international implications.

\section{Climate Adaptation in Australia}

The Australian Federal Government has limited its role in climate change adaptation to the provision of scientific research and information, managing national assets and programs, providing leadership, and maintaining both a strong, flexible economy, and social safety (Productivity Commission 2012). It has also negotiated agreements with the state/territory ${ }^{1}$ and local governments through the Council of Australian Governments (COAG). COAG has recently been replaced by a new structure based on the National Cabinet created to respond to the COVID-19 pandemic, and consists of state and national leaders (Hitch 2020). The Australian Constitution does not grant specific powers to the federal government in either natural resource management, conservation, land use planning, development, coastal management, climate change adaptation, or disaster risk management, so these fall to the states as residual powers (Parliament of Australia 2009). The two mainland territories, the Australian Capital Territory (ACT) and the Northern Territory (NT), have been granted a limited right of self-government and are governed by a locally-elected parliament (Australian Government n.d.), although the Australian government has greater power to intervene (COAG 2011).

Local governments are not mentioned in the constitution and exist entirely at the behest of state legislation (Mosadeghi et al. 2009, Norman 2009). They have been given land use planning powers and adapting to SLR is principally viewed as a local government responsibility (Reisinger et al. 2014, Preston et al. 2015). However, as Nalau et al. (2015: 89) demonstrate, devolving adaptation responsibility to local governments is fraught with risks, including inaction due to a lack of clear divisions of responsibility and "strong constraints and value conflicts at local levels of governance". Torabi et al. (2018) illustrate the importance of local politics, community demands, and development industry pressure in shaping local adaptation responses. Measham et al. (2011) and Mukheibir et al. (2013) point to competing planning agendas at the local

\footnotetext{
${ }^{1}$ The main difference between states and territories relates to their governing powers. The Australian states started as separate colonies before the federal government was created and state laws are protected by the constitution, whereas territories are limited by the power granted to them by the federal government (Judd 2018).
} 
level as a barrier to adaptation. Even when adaptation is high on the local agenda, it can still be constrained by lack of adaptive capacity, for example by misuse of coastal climate change risk assessments because of confusing terminology (Tonmoy et al. 2018b). Moreover, some adaptation options such as planned retreat carry large political risks that deter local governments (Gibbs 2016).

When national and state governments do not provide clear guidance, important decisions are left to the discretion of local councils with varying degrees of resources, capacities, and political support (Byrne et al. 2009, Gero et al. 2012, Baker et al. 2012). Gurran et al.'s (2013: 108) audit of climate adaptation in coastal Australia concluded that local governments are constrained by "the lack of a clear and consistent national level framework for integrated coastal planning and management, inadequate state and territorial policy and legislation, and significant resource constraints". Case studies from around the world suggest that local adaptation can be constrained by broader governance arrangements and policy (Lawrence et al. 2013, Oulahen et al. 2018, Torabi et al. 2017a), requiring a more streamlined higher-level focus. Other researchers have supported the need for local governments to be given more guidance (Vasey-Ellis 2009). Reisinger et al.'s (2014) examples of New South Wales (NSW) and Queensland (QLD) indicate how the suspension or revocation of long-term planning benchmarks gave local governments broad discretion in adaptation planning.

The absence of policy direction from national governments leave the onus of adaptation on state and local governments. While this can create opportunities for lower levels in countries where central governments hamper climate mitigation and adaptation, more often it results in vastly different responses across states and local governments, at times between jurisdictions in close proximity and facing similar challenges (Zahran et al. 2008, Torabi et al. 2017a, 2017b). The inconsistency can undermine existing efforts and/or lead to maladaptation at regional scales. The danger of allowing such a patchwork of arrangements to continue is that it leaves a considerable proportion of the population vulnerable to the impacts of climate change where no action is taken. Even worse, the fact that impacts such as flooding do not stop at jurisdictional boundaries means that the lack of action by one council could undermine adaptation strategies in adjacent councils. To give a simple example, if one council builds a barrier along its coast to defend against storm surges and rising sealevels, but the adjoining council does not, water will simply pass around the end of the 
barrier and flood both. Over the last 50 years, there have been 25 national inquiries and reports into coastal management. All have called for clearer and more consistent national leadership and guidelines on coastal development in order to promote the sustainable use of Australia's coastal zone as well as address growing concerns about climate change impacts (Norman and Church 2011, Parliament of Australia 2009).

\section{Coastal Climate Adaptation}

Adaptation is defined as "the process of adjustment to actual or expected climate and its effects" in order to moderate harm and exploit beneficial opportunities (IPCC 2014: 1785). The Coastal Zone Management Subgroup of the IPCC identifies the most common adaptation strategies as:

(1) Protection, involving the defence of vulnerable areas by decreasing the probability of the occurrence of a negative event where population, economic activity, and natural resources are located;

(2) Accommodation, allowing the continued use of vulnerable areas while enhancing the capacity of the natural and built environment and people to cope with impacts; and,

(3) Retreat, referring to the abandonment of land and structures in vulnerable and highrisk areas and their relocation/resettlement to safer areas (Dronkers et al. 1990).

Adaptation strategies can also be categorised by types of measures used (Dedekorkut-Howes et al. 2020). Structural measures include technological and engineering approaches. Non-structural measures include legal, institutional, and organisational measures such as legislation, policies, planning and management instruments, and public awareness raising (Dawson et al. 2011, Idllalène and Van Cauwenbergh 2016, Lee 2014). Hard measures consist of the use of physical (engineering) structures. Soft or ecosystem-based measures focus on natural solutions (Cisneros Linares 2013, Douglas et al. 2012). Structural measures can include both hard protection (such as seawalls, dikes, dams) as well as soft measures (typically beach nourishment and protection or construction of salt marshes and wetlands, etc.) (Lee 2014). 


\section{Methods}

We evaluated policies of the Australian national government and all coastal state and mainland territories against criteria, including legislative frameworks, coastal adaptation policies, SLR benchmarks for planning, and the level of detail on the structural and nonstructural adaptation measures. These criteria capture the main coastal adaptation strategies identified in the literature (Dedekorkut-Howes et al. 2020). We first prepared a working table that collates the information on these criteria for each state/territory (see Supplementary Material). We used this table to make our assessments. We colour-coded our analysis (from red [largely absent] to a light to dark shading of yellow [mentioned], light green [discussed], and dark green [details provided]) to illustrate the differences between jurisdictions across different criteria. We then scored each jurisdiction's policies using a four-point scoring system following similar qualitative policy-scoring approaches (Baker et al. 2012, Dedekorkut-Howes and Vickers 2017). The scoring was reviewed by two authors to limit the researcher interpretation bias this method may entail.

\section{National Coastal Adaptation Policies}

Australia has not had a national coastal policy since the lapse of the Commonwealth Coastal Policy 1995 that promoted ecologically sustainable land use (Parliament of Australia 2009). The national focus on climate change and coastal adaptation has been in flux for a decade - rising or falling depending on current politics and the party in power (Climate Council 2016, Howes and Dedekorkut-Howes 2016, 2017).

The adoption of the National Climate Change Adaptation Framework by COAG in April 2007 and the Rudd Labor Government's establishment of the Department of Climate Change put climate adaptation firmly on the national political agenda. The framework called for national assessments in key sectors and regions to support informed decision-making. This led to a series of reports and inquiries, as well as the establishment of the National Climate Change Adaptation Research Facility. The report of one of these inquires (Parliament of Australia 2009) considered a possible SLR in the range of $0.5-1.0 \mathrm{~m}$ by 2100 and made 47 recommendations, including more funding and research. The Department of Climate Change published a first pass national assessment (i.e. an initial estimate) of the impacts of a SLR of $1.1 \mathrm{~m}$ by 2100 (DCC 2009) that found residential buildings valued at up to AU\$63 billion in total were potentially at 
risk of coastal inundation. The National Coasts and Climate Change Council was established in 2009 as an advisory body to the Minister for Climate Change and Energy Efficiency (formerly DCC) but was discontinued in 2011 (Gurran et al. 2013). Another report (DCCEE 2011a) quantified the economic value of homes, offices, and infrastructure at risk of $1.1 \mathrm{~m}$ SLR by 2100 . All these assessments focussed on SLR by the end of this century, not taking into account any changes beyond leading to much higher levels that need to be dealt with in the longer term. The melting of the Greenland ice sheets alone, for example, would add seven metres to SLR (Lenton et al. 2019). The government also commissioned a study to inform the Coasts and Climate Change Council of the current status of Australian state and territory laws addressing coastal climate change (DCCEE 2011b). This report found great variance between jurisdictions, with no policies in either Tasmania (TAS) or NT, and those in Western Australia (WA) covering a limited range of issues. COAG's National Strategy for Disaster Resilience (COAG 2011) called for the integration of the impacts of SLR and extreme weather events into land use planning schemes, building codes, and state/territory regulations. The Productivity Commission's (2012) inquiry report into the barriers to climate adaptation proposed better integration of adaptation measures into land use planning, building regulations/codes, as well as the adoption of adaptive responses for existing settlements. It suggested a limited role for the national government, placing greater reliance on adaptation through market exchanges. The Climate Adaptation Outlook report (Australian Government 2013) proposed a National Adaptation Assessment Framework; however, the change of government to the conservative Abbott LiberalNational Coalition in 2013 halted or reversed most climate- related initiatives (Dedekorkut-Howes and Howes 2014) and interest in pursuing the objectives of the report waned.

The change in leadership of the Coalition to the Turnbull government in 2015 brought climate change adaptation back to the agenda (Howes and Dedekorkut-Howes 2017). A National Climate Resilience and Adaptation Strategy discussed the coastal impacts of climate change and SLR without providing sea level benchmarks but supported the need for extensive and integrated coastal planning, risk assessment (including legal), and scientific understanding of coastal and climate processes (Commonwealth of Australia 2016). In 2016 the federally-funded National Climate Change Adaptation Facility released the CoastAdapt website that contains a range of 
on-line resources designed to help coastal communities adapt to the impacts of climate change (Palutikof et al. 2018). The Australian Government also funded the interactive Coastal Risk Australia website in 2017 which allows users to assess the risks of coastal flooding. The Australian Infrastructure Plan (Infrastructure Australia 2016) underscores the importance of building resilience to climate change impacts and SLR. More recently, the Australian Parliament led an inquiry into the Government's role in the development of cities (Commonwealth of Australia 2018) that highlights the importance of building resilience to climate change impacts especially in coastal cities but fails to provide recommendations. The Australian Government also funded the Planning Institute of Australia to prepare national guidelines for disaster resilient communities (Australian Government 2016) focusing on the role of land use planning in building resilience. Following another leadership change in the Liberal-National Coalition to the more conservative Morrison government in late 2018, action on climate change halted yet again and became a major issue during the 2019 federal election. After being returned to power, however, the Morrison government refused to change course and was strongly criticised for its handling of the 2019-2020 bushfires. Several members of the government appeared to downplay climate change as a key driver of these fires and the preceding droughts (Daley and Millane 2020). This reignited concerns that the conservative government was not doing enough on the issue of climate change. Proposals for a gas-led coronavirus economic recovery from the National COVID-19 Coordination Commission, an advisory body to the Federal Government, seems to confirm these concerns (Morgan and Long 2020).

\section{State and Territory Coastal Adaptation Policies}

The lack of national coastal adaptation policies and SLR guidelines has led to a wide variation in state-level responses that leaves a large proportion of the population vulnerable and risks undermining adaptation actions where there is a spill-over risk between adjacent jurisdictions (see Figure 1). This is exacerbated by major differences in population distribution and levels of vulnerability (Table 1). The following sections provide a detailed overview of the relevant policies in each state and the NT excluding the land-locked ACT (summarised in Tables 2 and 3).

[Insert Table 1 about here] 
[Insert Table 2 about here]

[Insert Table 3 about here]

\section{New South Wales}

Australia's most populous state has many assets at risk (Table 1). The Coastal Management Act 2016 reformed management of coasts, focusing on reducing climate change risks and improving resilience. It facilitates the identification of land for acquisition to promote the protection and restoration of the coastal environment. The Act mentions beach erosion, shoreline recession, and coastal and tidal inundation, but ignores SLR. Local councils are required to develop Coastal Management Programs within their boundaries; however, NSW no longer prescribes a state SLR benchmark, abandoning previous benchmarks of the NSW Sea Level Rise Policy Statement (2009) ( $0.4 \mathrm{~m}$ by 2050 and 0.9 by 2100 ). Instead it allows councils the flexibility to determine SLR projections to suit their local conditions. The Local Government Act 1993 and its regulation enable councils to levy annual charges for the construction of defensive infrastructure. The Local Government Amendment (Climate Change) Bill 2017 requires councils to adapt to the impacts of climate change on people, communities, and ecosystems via 5-year action plans.

The State Environmental Planning Policy (Coastal Management) 2018 includes detailed strategies for coastal adaptation and prohibits development in high risk areas unless there is appropriate risk management. The 2018 NSW Coastal Management Manual guides local councils in preparation of their Coastal Management Programs in accordance with the Coastal Management Act. For adaptation to climate change and SLR the manual includes structural and natural coastal protection strategies, enhancing resilience of coastal ecosystems, and accommodation of impacts through urban design. The manual refers to the Coastal Design Guidelines for NSW (2003) that promote setting back properties from the waterfront. The State Infrastructure Strategy 20182038, Climate Change Policy Framework (2016), and State Emergency Management Plan 2018 mention coastal climate change impacts and SLR but focus mainly on non- 
structural strategies such as data collection, research, and identifying key roles and responsibilities. The state's Future Transport Strategy 2056 also acknowledges coastal impacts but fails to suggest strategies. The NSW Critical Infrastructure Resilience Strategy 2018 acknowledges climate change but does not specify coastal infrastructure. The six coastal regional plans prepared by the state government similarly emphasize non-structural strategies such as improving regional hazard resilience and reviewing/updating floodplain risk and coastal zone management plans. The Greater Sydney, South East and Tableland Regional, and North Coast Regional Plans prohibit development in high risk coastal areas and include accommodation strategies. The latter also proposes natural enhancement of coastal wetlands and allows for their landward migration. Only the Greater Sydney Plan considers managed retreat of development in exceptional circumstances without proposing specific actions.

\section{Victoria}

Victoria's (VIC) Climate Change Act 2017 requires the preparation of a state Climate Change Strategy and adaptation action plans. The Planning and Environment Act 1987 mentions SLR and other coastal impacts. The Direction No.13 Managing Coastal Hazards and the Coastal Impacts of Climate Change of the Planning Act requires explanatory reports on how proposed developments would address the current and future risks of SLR, storm surges, flooding, and coastal erosion. The key state policies that address coastal climate change impacts (Victorian Planning Provisions 2018, Victorian Coastal Strategy 2014, Victorian Coastal Hazard Guide 2012) require consideration of $0.8 \mathrm{~m}$ of SLR by 2100 and propose strategies for avoiding development in high risk areas, the protection of assets/infrastructure, natural and structural accommodation of impacts, and planned retreat. The Future Coasts Program provides a package of tools that include inundation maps and planning guidelines. The Victorian Coastal Hazard Guide (2012) was the first step in developing a state-wide approach to coastal hazards. The Marine and Coastal Act 2018 promotes the resilience of marine and coastal ecosystems, communities, and assets to climate change and respecting natural processes in planning for and managing current and future risks to people and assets. Victoria's Marine and Coastal Reforms Final Transition Plan (2018), aims to provide clear planning and controls for the access, use, and development of the coast by revising SLR planning benchmarks and targets, the siting and design guidelines for 
coastal structures, building capacity, guidance and support, and developing regulations for development of coastal state-owned land. The Victoria State Emergency Service Community Resilience Strategy 2016-2019 considers SLR to be a chronic stress and emphasises non-structural measures such as capacity building, increased collaboration, and fostering connections between the community and emergency services to address climate change impacts. At the regional level, Gippsland, Central, and Western Coastal plans consider coastal impacts. All three plans refer to a SLR of not less than $0.8 \mathrm{~m}$ by 2100. In accordance with the "valuing the natural environment" objective of the Victorian Coastal Strategy 2014, these plans focus on coastal hazard assessment, local adaptation planning, and implementing adaptation responses through planning. They include detailed adaptation responses and strategies to protect and accommodate the impacts and planned retreat/relocation of existing settlements. Other regional coastal plans including the metropolitan plan, Plan Melbourne, are much less detailed.

\section{Queensland}

QLD is one of the most vulnerable states to the coastal climate change impacts (Table 1). Both climate change and coastal policy in QLD has been on a roller coaster fluctuating wildly between the extremes of national leadership to neglect depending on the party in power (Dedekorkut et al. 2010, Howes and Dedekorkut-Howes 2017). While state legislation covers flooding, storm surge inundation, erosion, and cyclones, only the Coastal Protection and Management Act 1995 and Planning Act 2016 specifically mention adaptation. The Coastal Protection and Management Regulation 2017 requires a $0.8 \mathrm{~m}$ SLR by 2100 to be embedded in the design and construction of tidal works. The key state policies on coastal matters include the State Planning Policy (2017) and the Coastal Management Plan (2013). The former deals with land use planning and development and the latter provides guiding principles on matters such as the rehabilitation of the coast, public access, etc. The $0.8 \mathrm{~m}$ of SLR also appears in other state policies, including the Queensland Climate Adaptation Strategy 2017-2030, the State Development Assessment Provisions (SDAP) (2017), and the State Infrastructure Plan (2016). The Adaptation Strategy introduced the QCoast2100 program that offers funding, tools, and technical support to 45 coastal councils for coastal hazard adaptation planning. The Minimum Standards and Guidelines for Queensland Local Governments (2016) help local councils develop Coastal Hazard Adaptation Strategies for a default 
storm tide level of $1.5 \mathrm{~m}$ for South East Queensland and $2 \mathrm{~m}$ above the Highest Astronomical Tide for the rest of the state.

Overall QLD's statutory responses range from prohibition of development and infrastructure in high-risk areas to construction of physical and natural protection, and accommodation of impacts via the State Planning Policy, Coastal Management Plan, and $S D A P$. None of the coastal regional plans mention protective structures such as seawalls. The Wide Bay Burnett, Far North Queensland, and Mackay, Isaac and Whitsundays regional plans provide detailed instructions for avoiding and minimising the coastal impacts on development and infrastructure and promote landward retreat of coastal habitats and ecosystems. Despite covering the most developed part of the state, the South East Queensland Regional Plan 2017 does not provide any guidance on structural or natural adaptation measures. Its Climate Change theme mentions the importance of enhancing the natural capacity of the coast to buffer people, infrastructure, and biodiversity from the impacts of extreme events. An important feature of the Queensland Climate Adaptation Strategy is the sectoral adaptation plans for agriculture, tourism, built environment and infrastructure, human health and wellbeing, emergency management, and biodiversity and ecosystems. While all sector plans acknowledge the coastal climate change impacts, only the Emergency Management (Tonmoy et al. 2018a) and Biodiversity and Ecosystems (Moran and Boulter 2018) plans include SLR benchmarks, identifying priority areas of action. Despite QLD's high level of vulnerability, there is hardly any mention of planned retreat and relocation away from high risk areas (with the exception of Central Queensland Regional Plan and the non-statutory guidelines for State Code 8 that consider retreat as a preferred option for areas under imminent threat from coastal erosion). They do, however, prohibit new developments in high risk areas.

\section{Western Australia}

WA does not have a coastal management legislation, nor do its other legislation and regulations mention climate change or SLR. The State Planning Strategy 2050 (2014) provides strategic direction for state, regional, and local planning matters and features climate change, highlighting adaptation to coastal impacts such as flooding and storm surges by enhancing the resilience of ecosystems. The key state policies that address adaptation to SLR and related coastal hazards are the State Coastal Planning Policy 
(SPP 2.6) and its Guidelines (2013), WA Coastal Zone Strategy (2017) and the Coastal Hazard Risk Management Adaptation Planning Guidelines (2019). These policies include a SLR of not less than $0.9 \mathrm{~m}$ by 2110 and discuss strategies for natural and structural protection of the coast, accommodation of impacts, retreat/relocation of highrisk settlements, and prohibition of further development in some areas. The SPP 2.6 proposes structural and natural coastal protection as the last option, after ensuring that other strategies are exhausted. The 2019 Coastal Hazard Risk Management and Adaptation Planning Guidelines refer to the Sea Level Change in Western Australia, Application to Coastal Planning (2010), a detailed technical guide focused on historical as well as short and long-term changes in sea levels that recommended the adoption of the upper bound of the IPCC global SLR projections $(0.9 \mathrm{~m}$ by 2100$)$ plus $0.01 \mathrm{~m} /$ year for every year beyond. An appendix to the guidelines entitled Planned or managed retreat outlines the instruments in the existing planning framework with which planned/managed retreat could be implemented including structure planning, local planning scheme amendment, and voluntary or compulsory taking of land. The WA regional plans do not include a SLR benchmark and particularly focus on accommodation of coastal impacts by design and management of infrastructure and development, changes to existing land uses, and avoiding high risk areas.

\section{South Australia}

The Coastal Protection Act 1972 established a Coast Protection Board that can authorise repairing/restoring damage caused by coastal storms and acquire coastal land. South Australia (SA) is the first Australian state to introduce a SLR policy in its planning regulations mainly driven by the Coast Protection Board's 1991 Policy on Coast Protection and New Coastal Development, which adopted a SLR allowance of $0.3 \mathrm{~m}$ by 2050 and $1 \mathrm{~m}$ by 2100 to be embedded in development plans. The key legislation relevant to land use and development, Planning, Development and Infrastructure Act 2016, requires a state policy which promotes climate change resilient development. The Act discusses coastal protection works and sand replenishment but does not mention SLR or other coastal hazards. The Development Regulations 2008 prepared under the previous Development Act (1993) provide more detail on development and provisions without any mention of coastal impacts. The Coast Protection Board's Policy Document (2016) sets similar coastal flooding and erosion 
standards for new developments. The South Australian Planning Policy Library sets out policies for prohibition of development in high risk tidal areas, natural and structural protection, and accommodation of coastal impacts. Of the new State Planning Policies (2019) Policy 5 focuses on climate change adaptation and Policy 13 includes protection and enhancement of the coastal environment by avoiding, accommodating, adapting, and coastal retreat.

SA's adaptation framework Prospering in a Changing Climate (2012), Climate Change Strategy 2015-2050, and Adaptation Action Plan (2017) include strategies for accommodating SLR impacts and allowing for retreat of coastal settlements and ecosystems. The first SA infrastructure strategy that acknowledged climate change impacts and SLR was the Strategic Infrastructure Plan for SA 2005/6-2014/15. The new 20-Year State Infrastructure Strategy (2020) exemplifies how climate change impacts can be addressed during infrastructure planning through undertaking analysis during infrastructure scoping and design to understand potential impacts of projected SLR on volumes, quality, and timing of stormwater flows and associated infrastructure design requirements. Its coastal adaptation strategic priority is implementing the Living Coast Strategy (2004), which sets out the state's environmental policy directions for sustainable management of coastal and marine environments. The five-year strategy has not been replaced. In May 2020, the Local Government Association of South Australia released the Draft Coastal Adaptation Guidelines, which aim to provide support to councils in assessing and quantifying the likely impacts of coastal inundation and erosion as a result of climate change, for comment to councils. The document is not yet publicly available.

Unlike other states, SA's regional land use and climate change adaptation plans include detailed consideration of SLR projections and a variety of strategies from natural and structural protection to accommodating impacts and minimising risks to settlements and infrastructure. Three regional adaption plans (Western Adelaide, Far North and Outback, and Southern Adelaide) outline the creation of a living shoreline by using oyster beds as an alternative to structural measures. SA's regional plans also emphasise prohibiting development in high risk coastal areas, retreat of settlements and infrastructure, and compulsory land acquisition. 


\section{Tasmania}

Like WA, TAS does not have a coastal legislation and its Climate Change Act 2008 excludes adaptation. The Coastal Policy 1996 focuses on the protection of natural and cultural values, sustainable development, and shared responsibility for integrated management. The 2013 Tasmanian Coastal Policy Statement Consultation Draft published as an update of the Coastal Policy considers climate change and refers to the Derivation of the Tasmanian Sea Level Rise Planning Allowances Technical Paper (2012), which allows for $0.2 \mathrm{~m}$ by 2050 and $0.8 \mathrm{~m}$ by 2100 SLR. The Natural Assets Code (C7.0) refers to the Tasmanian Coastal Works Manual (2010) which specifically focuses on coastal adaptation and considers $0.79 \mathrm{~m}$ of SLR by 2100 and between $1-1.5 \mathrm{~m}$ depending on ice-sheet responses. The Coastal Erosion and Hazards and Coastal Inundation Codes aim to minimise the costs of retreat of property and infrastructure, but do not mention specific actions. The Planning Directive No. 4.1 Standards for Residential Development in the General Residential Zone (2014) suggests local provisions for areas subject to SLR, storm surge, coastal inundation, or coastal erosion but falls short of providing specific standards. The only state policy that provides a SLR benchmark (between $0.39 \mathrm{~m}$ and $0.89 \mathrm{~m}$ by 2090 ) is Tasmania's Climate Change Action Plan (2017) that focuses on the coastal risks of an increase in storms, erosion, and inundation. While the Coastal Policy and State Planning Scheme (including Coastal Erosion and Coastal Inundation Hazard Codes) mention enhancing the natural capacity of the coast and minimising risks to development, no policy includes provisions to prohibit development in high risk areas or retreat of existing settlements. All three regional strategies, however, include best practices for managing coastal risks to development and infrastructure, natural accommodation of impacts, prohibiting development in high risk areas. The Cradle Coast Regional Framework mentions retreat. The Northern Tasmania Regional Land Use Strategy acknowledges climate change impacts and promotes a precautionary approach to SLR and the location of new development. Both state and regional policies focus on non-structural coastal adaptation strategies such as hazard identification and mapping, public participation, and emergency management. 


\section{Northern Territory}

NT legislation does not include a coastal policy nor mention climate change. While the very small population of the territory (Table 1) may explain this to a certain extent, its high vulnerability was illustrated tragically by Tropical Cyclone Tracy's devastation of its capital Darwin in 1974, a pivotal moment in Australia's history of natural disasters (Figure 2). The Northern Territory Planning Scheme limits development of Primary Storm Surge Areas (areas within a 1\% Annual Exceedance Probability [AEP] of storm surge inundation) to open space/recreation and Secondary Storm Surge Areas (adjacent to the primary areas) to industrial or commercial use and avoids residential development. The scheme defines storm surge as the elevation in sea level that accompanies a cyclone near a coastline. It requires construction of defensive structures for commercial and residential buildings in Darwin's waterfront. Protection of the Darwin Foreshore project is included in the 10 Year Infrastructure Plans updated annually since 2017. The Northern Territory Climate Change Policy (2009) acknowledged the vulnerability of coastal wetlands to rising seas and climate change and promoted resilient communities that can live with change by rehabilitating coastal wetlands. The Climate Change Discussion Paper (2018) includes a SLR benchmark of $0.65 \mathrm{~m}$ to $0.87 \mathrm{~m}$ above 2005 levels by 2100 . The Environmental Guidelines for Reclamation in Coastal Areas (2006) that aim to minimise the impacts of reclamation on coastal habitats and coastal water quality do not cover climate change but mention the impacts of coastal erosion and tidal inundation on water quality. The Territory Emergency Plan (2019) acknowledges climate change in passing and sets out emergency management and warning requirements for coastal hazards. The Northern Territory All Hazards Emergency Management Arrangements also outline similar arrangements. The NT government has recently developed a Coastal and Marine Management Strategy 2019-2029, which focuses on resilience of coastal and marine ecosystems to climate change. The Darwin Regional Land Use Plan 2015 acknowledges climate change impacts and SLR and focuses on limiting land use intensification in the 1\% AEP flood and storm tide level, accommodating future impacts by locating new development above these levels, and adopting appropriate design responses.

[Insert Figure 2 about here] 


\section{Discussion}

Our assessment of each jurisdiction's performance (Table 4) shows that Australia is not well-prepared for SLR and coastal flooding. With the lack of strong national leadership, sub-national responses remain patchy across time and space. This leaves a large proportion of the population vulnerable and undermines adaptation actions where adjacent councils face a spill-over risk from impacts such as flooding. Overall, SA, VIC, WA, and QLD place greater focus on adapting to coastal climate change impacts in comparison to the other jurisdictions, which focus mostly on protecting and accommodating the impacts as opposed to retreating from the coast. As time progresses, the retreat of many coastal settlements will become more urgent for many local councils (Kellett et al. 2012); however, most state and territory governments (except for SA and WA) provide no clear guidance on how to undertake this transition. There is a major policy gap despite the urgency of the matter.

[Insert Table 4 about here]

This is not unique to Australia. Peterson's (2019) recent review of coastal relocation planning in the United States and Great Britain shows a similarly patchy pattern and serious gaps. Many researchers point out the cross-scale constraints on local governments caused by the absence of a whole-of-government approach and lack of leadership at the state and federal levels to adaptation planning (Measham et al. 2011, Mukheibir et al. 2013). Lack of leadership, guidance, and consistency of policy from higher levels of government; restrictive policies; shifting ideologies; and lack of funding constrain local level adaptation globally, including in Germany and the UK (Porter et al. 2015, Lorenz et al. 2016), Norway (Næss et al. 2005, Amundsen et al. 2010), New Zealand (Lawrence et al. 2013), Latin America (Lehmann et al. 2013), and Canada (Oulahen et al. 2018). The responsibility for adaptation to coastal climate change impacts has largely been shifted to local governments without the necessary resources. Without a clear direction, guiding frameworks, or any requirement to address SLR and 
coastal adaptation from the national level, state governments also struggle to prioritise adaptation and effectively respond to climate change impacts (Harvey et al. 2012b, Gero et al. 2012, Torabi et al. 2017a). Without the political will at higher levels of government to take climate adaptation action, many local communities will be at risk of rising sea levels and coastal flooding. The vulnerability of the population in return burdens government at all levels financially and puts them at risk of litigation. This is evidenced by the toll of disasters for governments (e.g. the 2011 Queensland floods led to an insurance pay-out of AU\$2.4 billion (Productivity Commission 2014)).

Some of the differences in coastal adaptation between Australian states and territories may reflect their experience of coastal hazards. SA's strong coastal adaptation response, for example, is mainly attributed to the establishment of the Coast Protection Board in response to extensive erosion across the state, and the Board's rigorous policies on addressing SLR and coastal impacts, particularly natural protection of the beaches, for more than 30 years (Deans et al. 2003). However, historical policy fluctuations point to the local political context, and to the ideologies and whims of governing political parties, rather than to levels of vulnerability or experience in explaining differing levels of adaptation. The reversals in QLD SLR policy between the Liberal National and Labor Governments (Torabi et al. 2017a), and revision of the Victorian SLR planning benchmark of $0.8 \mathrm{~m}$ by 2100 established in 2008 downwards to $0.4 \mathrm{~m}$ with a change of government in 2012 (Gurran et al. 2013), provide striking examples. A direct comparison between our findings and a previous assessment (DCCEE 2011b) does not reflect the interim changes that have occurred in QLD, as the current QLD government is reverting back to the policies that were present during the previous assessment. However, it highlights policy changes in WA for the better and NSW for the worse.

The lack of consistent long-term higher-level policy both at federal and state level (except maybe in SA) is a significant roadblock to adaptation at the local level. Planning for coastal adaptation in QLD is a case in point. The 2012 Queensland Coastal Plan required coastal councils across the state to prepare coastal hazard adaptation plans but within a year, before adaptation plans were prepared in most coastal councils, the Coastal Plan was scrapped due to a change of government (Dedekorkut-Howes and Howes 2014). In the absence of federal level guidance, even when local governments want to take action their efforts can be undermined by states. This is evidenced in the 
QLD state government's intervention in Moreton Bay Regional Council to remove any references to SLR from the local planning scheme for political reasons (Solomons and Willacy 2014). The latest change of state government in QLD saw renewed support for the preparation of local coastal hazard adaptation strategies restarting the cycle of planning. If it gets disrupted yet again with a change of government, there will be further waste of money, time, and effort without achieving any tangible adaptation outcomes. Requirements and guidance from higher levels are critical for consistent levels of adaptation across time and space.

These policy reversals at both the national and state levels of government occur due to a number of factors (Howes and Dedekorkut-Howes 2016). First, there is political opportunism within political parties. In 2009, for example, Tony Abbott saw an opportunity to seize the leadership of the federal parliamentary Liberal party by reversing his former support for climate policies (including the National Climate Change Adaptation Framework) and thereby gaining the allegiance of the conservatives within his party. He then went on to make the costs of the Labor government's climate change policies a major election issue. The second factor is economic. The Australian economy has a significant resources sector and fossil fuels are a major export. No politician wants to be seen to be threatening the jobs in the coal industry (which has been a consistent opponent of climate action). This has led some conservative politicians to deny that the climate is changing and assert that no action on either mitigation or adaptation is necessary. The state of Queensland, for example, is a major coal producer and the Newman conservative government of 2012-2015 directed coastal councils not to take SLR into account in their city plans. Finally, there is the ideological factor. Dryzek (2013) outlines a range of discourses that have been influential in the politics of the environment. Those on the right wing of politics (who are the main inhabitants of the Liberal-National party Coalition) often advocate views consistent with the promethean discourse that economic growth can go on forever, or the economic rationalist view of the market always producing the best outcomes. In this view, adaptation is either unnecessary, if it is matched with climate change denial (as in the Newman government example above), or is something that can be left to the market. In the latter view, property owners, insurers and financial institutions decide on the level of risk that they find acceptable and choose to undertake only those adaptive changes that produce more benefits than costs.. 


\section{Conclusions}

Our review of Australian SLR and coastal flooding policies shows that Australia is not ready for SLR and coastal flooding. The findings have three major implications for policy both nationally and internationally: (1) In the absence of national guidance and leadership, climate adaptation responses will remain uneven across lower level jurisdictions, leaving a significant proportion of the population vulnerable and undermining current adaptation actions. Variations occur between states in the absence of national benchmarks and between local councils where there are no state benchmarks. Local governments need clear and ongoing national leadership as well as guidelines on coastal development to ensure more consistent responses at local levels. (2) National, state and territory policies or plans are more effective if they are consistent over time, but they are undermined by ongoing reversals when governments change between political parties that have widely varying views on climate change. (3) Effective long-term adaptation policymaking and planning therefore require a bipartisan commitment and consistent political will across the major political parties to prioritise the problem and commit significant public resources to a response.

Governments across the world need a much stronger approach to coastal adaptation, underpinned by robust and coherent policy guidance from higher levels and complemented by strong leadership of the national government. Consistency of policy vertically across different levels of government and horizontally across neighbouring jurisdictions - along with continuity in time is critical for the success of adaptation efforts. In the absence of such an approach, the highly political SLR policy reversals will continue, potentially leaving the adaptation planning and policy context very confusing for local governments and endangering the lives of people.

\section{Acknowledgements}

We would like to thank the anonymous reviewers and the editor for their constructive feedback that strengthened our paper. 


\section{References}

Australian Bureau of Statistics (ABS). (2018). 3101.0 - Australian Demographic Statistics, Mar 2018 http://www.abs.gov.au/ausstats/abs@.nsf/mf/3101.0 Australian Government. (n.d.). State and territory government. https://info.australia.gov.au/about-government/how-government-works/stateand-territory-government. Accessed 28 August 2020.

Australian Government. (2016). National land use planning guidelines for disaster resilient communities. Canberra, ACT.

Australian Government. (2013). Climate adaptation outlook. Canberra.

Amundsen, H., Berglund, F. and Westskog, H. (2010). Overcoming barriers to climate change adaptation - A question of multilevel governance? Environment and Planning C: Politics and Space, 28, 276-289.

Baker, I., Peterson, A., Brown, G. and McAlpine, C. (2012). Local government response to the impacts of climate change: An evaluation of local climate adaptation plans. Landscape and Urban Planning, 107, 127-136.

Bradley, M., van Putten, I. and Sheaves, M. (2015). The pace and progress of adaptation: Marine climate change preparedness in Australia's coastal communities. Marine Policy, 53, 13-20.

Byrne, J., Gleeson, B., Howes, M. and Steele, W. (2009). Climate change and Australian urban resilience: The limits of ecological modernization as an adaptive strategy. In: Mehmood, A., Crawford, J. and Davoudi, S. (Eds.). Planning for climate change: Strategies for mitigation and adaptation for spatial planners (pp. 136-154). London: Routledge.

Cisneros Linares, P.B. (2013). Sea level rise impacts in coastal zones: Soft measures to cope with it. Dalhousie Journal of Interdisciplinary Management, 8, 1-16.

Clarke, B. (2010). Analysis of Coastal Policies of Australian State and Territory Governments. Report prepared for the South Australian Coast Protection Board, Department of Environment and Natural Resources. DOI: 10.13140/RG.2.1.3269.7767

Climate Council. (2014). Lagging behind: Australia and the global response to climate change. Potts Point, Sydney: Climate Council of Australia Ltd. 
Commonwealth of Australia. (2018). Building up \& moving out: Inquiry into the Australian Government's role in the development of cities. Canberra: House of Representatives Standing Committee on Infrastructure, Transport and Cities.

Commonwealth of Australia. (2016). National climate resilience and adaptation strategy. Canberra.

Council of Australian Governments (COAG). (2011). National strategy for disaster resilience. Canberra: Commonwealth of Australia.

Council of Australian Governments (COAG). (2007). National climate change adaptation framework. Canberra, COAG.

Daley, J. and E. Millane. (2020). Might the bushfire crisis be the turning point on climate politics Australian needs? The Conversation. Retrieved from: https://theconversation.com/might-the-bushfire-crisis-be-the-turning-point-onclimate-politics-australian-needs-129442

Dawson, R.J., Ball, T., Werritty, J., Werritty, A., Hall, J. W. and Roche, N. (2011). Assessing the effectiveness of non-structural flood management measures in the Thames Estuary under conditions of socio-economic and environmental change. Global Environmental Change, 21(2), 628-46.

Deans, J.A., Tucker, R. and Townsend, M. (2003). The Coast Protection Board of South Australia 30 years of rebuilding Adelaide's beaches... and plans for the next 30 years. In Kench, P.S. and Hume, T.M. (Eds.). Coasts \& ports 2003 Australian conference: Proceedings of the $16^{\text {th }}$ Australian coastal and ocean engineering conference. Barton, ACT: Institution of Engineers Australia.

Dedekorkut-Howes, A., Torabi, E. and Howes, M. (2020). When the tide gets high: A review of adaptive responses to sea level rise and coastal flooding. Journal of Environmental Planning and Management, 63(12): 2102-2143.

Dedekorkut-Howes, A. and Howes, M. (2014). Climate adaptation policy and planning in South East Queensland. In Burton, P. (Ed.) Responding to climate change: Lessons from a hotspot (pp. 59-67). Collingwood, VIC: CSIRO Publishing.

Dedekorkut-Howes, A. and Vickers, J. (2017). Coastal climate adaptation at the local level: A policy analysis of the Gold Coast. In Filho, W.L. (Ed.) Climate change adaptation in Pacific countries: Fostering resilience and improving the quality of life (pp. 401-416). Cham, Switzerland: Springer International Publishing. 
Dedekorkut, A., Mustelin, J., Howes, M. and Byrne. J. (2010). Tempering Growth: Planning for the Challenges of Climate Change and Growth Management in SEQ, Australian Planner, 47 (3), 203-215.

Department of Climate Change (DCC). (2009). Climate change risks to Australia's coast: A first pass national assessment. Canberra: Commonwealth of Australia. http://www.climatechange.gov.au/ /media/publications/coastline/cc-risks-fullreport.pdf.

Department of Climate Change and Energy Efficiency (DCCEE). (2011a). Climate change risks to coastal buildings and infrastructure. Canberra: Commonwealth of Australia.

Department of Climate Change and Energy Efficiency (DCCEE). (2011b). Coastal climate change risk: Legal and policy responses in Australia. Canberra: Commonwealth of Australia. Retrieved from: http://www.environment.gov.au/climate-change/adaptation/publications/coastalclimate-change-risk.

Douglas, E.M., Kirshen, P.H., Paolisso, M., Watson, C., Wiggin, J., Enrici, A. and Ruth, M. (2012). Coastal flooding, climate change and environmental justice: Identifying obstacles and incentives for adaptation in two metropolitan Boston Massachusetts communities. Mitigation and Adaptation Strategies for Global Change, 17 (5), 537-62.

Dronkers, J. and Mulder, J. (2011). A sediment strategy for coastal zone climate change adaptation. Littoral 2010, 06001. DOI:10.1051/litt/201106001

Dryzek, J. (2013). The politics of the earth: Environmental discourses. $3^{\text {rd }} \mathrm{ed}$. Oxford: Oxford University Press.

Gero, A., Kuruppu, N. and Mukheibir, P. (2012). Cross-scale barriers to climate change adaptation in local government, Australia. Sydney: Institute for Sustainable Futures, University of Technology Sydney.

Gibbs, M. (2016). Why is coastal retreat so hard to implement? Understanding the political risk of coastal adaptation pathways. Ocean and Coastal Management, 130, 107-114.

Gibbs, M. and Hill, T. (2011). Coastal climate change risk - Legal and policy responses in Australia. Commonwealth of Australia, Department of Climate Change and Energy Efficiency. 
Gurran, N., Norman, B. and Hamin, E. (2013). Climate change adaptation in coastal Australia: An audit of planning practice. Ocean and Coastal Management, 86, 100-09.

Harvey, N., Clarke, B., Pelton, N. and Mumford, T. (2012a). Evolution of sustainable coastal management and coastal adaptation to climate change. In Kenchington, R., Stocker, L. and Wood, D. (Eds.), Sustainable coastal management and climate adaptation: Global lessons from regional approaches in Australia (pp. 75-101). Australia: CSIRO Publishing.

Harvey, N. Clarke, B., and Nursey-Bray, M. (2012b). Australian coastal management and climate change. Geographical Research, 50(4), 356-367.

Hitch, G. (2020). Scott Morrison says National Cabinet here to stay, will replace COAG meetings in wake of coronavirus. $A B C N e w s$. Retrieved from https://www.abc.net.au/news/2020-05-29/coag-scrapped-national-cabinet-hereto-say-coronavirus-update/12300636

Howes, M. and Dedekorkut-Howes, A. (2017). The adaptation roller-coaster: Planning for climate change on the Gold Coast, Queensland. Proceedings of the State of Australian Cities (SOAC) Conference, Adelaide, 28-30 November. DOI: $10.4225 / 50 / 5 b 2 \mathrm{f} 2 \mathrm{a} 0 \mathrm{a} 6 \mathrm{eecf}$

Howes, M., and Dedekorkut-Howes, A. (2016). The rise and fall of climate adaptation governance on the Gold Coast, Australia. In: Knieling, J. (Ed.) Climate adaptation governance in cities and regions: Theoretical fundamentals and practical evidence (pp. 237-250). Hamburg: John Wiley \& Sons, Inc.

Idllalène, S., and Van Cauwenbergh, N. (2016). Improving legal grounds to reduce vulnerability to coastal flooding in Morocco - A plea for an integrated approach to adaptation and mitigation. Ocean and Coastal Management, 120, 189-97.

Infrastructure Australia. (2016). Australian infrastructure plan: Priorities and reforms for our nation's future. Sydney, NSW.

Intergovernmental Panel on Climate Change (IPCC). (2018). Global warming of $1.5^{\circ} \mathrm{C}$. Special Report. IPCC Cambridge, UK: Cambridge University Press.

Intergovernmental Panel on Climate Change (IPCC). (2014). Climate change 2014: Impacts, adaptation, and vulnerability. Part A: Global and sectoral aspects. Contribution of Working Group II to the Fifth Assessment Report of the Intergovernmental Panel on Climate Change [Field, C.B., V.R. Barros, D.J. 
Dokken, K.J. Mach, M.D. Mastrandrea, T.E. Bilir, M. Chatterjee, K.L. Ebi, Y.O. Estrada, R.C. Genova, B. Girma, E.S. Kissel, A.N. Levy, S. MacCracken, P.R. Mastrandrea, and L.L. White (eds.)]. Cambridge, United Kingdom and New York, NY, USA: Cambridge University Press.

Kellett, J., Balston, J., Li, S., Wells, G. and Western, M. (2012). Responding to rising sea levels: The Australian experience. $6^{\text {th }}$ international conference and workshop on the built environment in developing countries (pp. 441-453). 4-5 December 2012. ICBEDC.

Lawrence, J., Sullivan, F., Lash, A., Ide, G., Cameron, C. and McGlinchey, L. (2013). Adapting to changing climate risk by local government in New Zealand: institutional practice barriers and enablers. Local Environment, 25(3), 1-31.

Lee, Y. (2014). Coastal planning strategies for adaptation to sea level rise: A case study of Mokpo, Korea. Journal of Building Construction and Planning Research, $2(01), 74$.

Lehmann, P., Brenck, M., Gebhardt, O., Schaller, S. and Süßbauer, E. (2013). Barriers and opportunities for urban adaptation planning: analytical framework and evidence from cities in Latin America and Germany. Mitigation and Adaptation Strategies for Global Change, 20, 75-97.

Lorenz, S., Dessai, S., Forster, P.M. and Paavola, J. (2016). Adaptation planning and the use of climate change projections in local government in England and Germany. Regional Environmental Change, 17, 425-435.

Measham, T.G., Preston, B. L., Smith, T.F., Brooke, C., Gorddard, R., Withycombe, G. and Morrison, C. (2011). Adapting to climate change through local municipal planning: Barriers and challenges. Mitigation and Adaptation Strategies for Global Change, 16(8), 889-909.

Moran, C. and S. Boulter. (2018). Biodiversity and ecosystems climate adaptation plan. Brisbane, Australia.

Morgan, E. and S. Long. (2020). Coronavirus economic recovery committee looks set to push Australia towards gas-fired future. $A B C N e w s$, https://www.abc.net.au/news/2020-05-13/coronavirus-recovery-to-pushaustralia-towards-gas-future/12239978. Accessed 28 August 2020. 
Mosadeghi, R., Tomlinson, R., Mirfenderesk, H., and Warnken, J. (2009). Coastal management issues in Queensland and application of the multi-criteria decision making techniques. Journal of Coastal Research, S1(56), 1252-1256.

Mukheibir, P., Kuruppu, N., Gero, A. and Herriman, J. (2013). Overcoming cross-scale challenges to climate change adaptation for local government: A focus on Australia. Climatic Change 121, 271-283.

Næss, L.O., Bang, G., Eriksen, S. and Vevatne, J. (2005). Institutional adaptation to climate change: Flood responses at the municipal level in Norway. Global Environmental Change, 15(2), 125-138.

Nalau, J., Preston, B.L. and Maloney, M.C. (2015). Is adaptation a local responsibility? Environmental Science \& Policy, 48, 89-98.

Norman, B. (2009). Principles for an intergovernmental agreement for coastal planning and climate change in Australia. Habitat International, 33, 293-299.

Norman, B. and Church, J. (2011). Scrapping sea level protection puts Australian homes at risk. The Conversation. Retrieved from: https://theconversation.com/scrapping-sea-level-protection-puts-australianhomes-at-risk-21271.

Oulahen, G., Klein, Y., Mortsch, L., O’Connell, E., and Harford, D. (2018). Barriers and Drivers of Planning for Climate Change Adaptation across Three Levels of Government in Canada. Planning Theory \& Practice, 19(3), 405-421.

Palutikof, J.P., Rissik, D., Webb, S., Tonmoy, F.N., Boulter, S.L., Leitch, A.M., Perez Vidaurre, A.C. and Campbell, M.J. (2019). CoastAdapt: An adaptation decision support framework for Australia's coastal managers. Climate Change, 153, 491507.

Parliament of Australia. (2009). Managing our coastal zone in a changing climate: The time to act is now. House of Representatives Standing Committee on Climate Change, Water, Environment and the Arts. Canberra.

Peterson, J. (2019) A new coast: Strategies for responding to devastating storms and rising seas. Island Press: Washington.

Porter, J., Demeritt, D. and Dessai, S. (2015). The right stuff? Informing adaptation to climate change in British Local Government. Global Environmental Change, 35, 411-422. 
Preston, B., Mustelin, J., and Maloney, M.C. (2015). Climate adaptation heuristics and the science/policy divide. Mitigation and Adaptation Strategies for Global Change, 20, 467-497.

Productivity Commission. (2014). Natural disaster funding. Canberra: Australian Government.

Productivity Commission. (2012). Barriers to effective climate change adaptation, Report No. 59, Final Inquiry Report. Canberra: Commonwealth of Australia. Reisinger, A., Kitching, R.L., Chiew, F., Hughes, L., Newton, P.C.D., Schuster, S.S., Tait, A. and Whetton, P. (2014). Australasia. In: Barros, V.R., Field, C.B., Dokken, D.J., Mastrandrea, M.D., Mach, K.J., Bilir, T.E., Chatterjee, M., Ebi, K.L., Estrada, Y.O., Genova, R.C., Girma, B., Kissel, E.S., Levy, A.N., MacCracken, S., Mastrandrea, P.R. and White, L.L. (Eds.). Climate change 2014: Impacts, adaptation, and vulnerability. Part B: Regional aspects. Contribution of Working Group II to the Fifth Assessment Report of the Intergovernmental Panel on Climate Change (pp. 1371-1438). Cambridge University Press, Cambridge, United Kingdom and New York, NY, USA. Solomons, M. and Willacy, M. (2014). Jeff Seeney orders Moreton Bay Regional Council to remove references to climate change-derived sea level rises from regional plan. $A B C$ News. Retrieved from: http://www.abc.net.au/news/2014-1209/seeney-removes-climate-change-references-from-council-plan/5954914. Accessed 12 Dec 2014.

Judd, B. (2018) Why isn't the Northern Territory a state? ABC News, https://www.abc.net.au/news/2018-02-27/why-isnt-the-northern-territory-astate-curious-darwin/9457776. Accessed 28 August 2020.

Ting, I., Scott, N., Palmer, A., and Slezak, M. (2019). The rise of the Red Zones of Risk. ABC News. Retrieved from: https://www.abc.net.au/news/2019-10-23/thesuburbs-facing-rising-insurance-costs-from-climate-risk/11624108. Accessed 25 October 2019

Tonmoy F.N., Thompson, M., Rolfe, J. and D. Rissik. (2018a). Emergency management sector adaptation plan for climate change in Queensland. Brisbane, Australia.

Tonmoy, F.N., Wainwright, D., Verdon-Kidd, D. C. and Rissik, D. (2018b). An investigation of coastal climate change risk assessment practice in Australia. Environmental Science and Policy, 80, 9-20. 
Torabi, E., Dedekorkut-Howes, A., and Howes, M. (2018). Adapting or maladapting: Building resilience to climate-related disasters in coastal cities. Cities, 72, 295309.

Torabi, E., Dedekorkut-Howes, A., and Howes, M. (2017a). Not waving, drowning: Can local government policies on climate change adaptation and disaster resilience make a difference? Urban Policy and Research, 35(3), 312-332.

Torabi, E., Dedekorkut-Howes A., and M. Howes. (2017b). Urban resilience to climaterelated disasters: Emerging lessons from resilience policy and practice in coastal tourism cities. In Filho, W.L. (Ed.) Climate change adaptation in Pacific countries: Fostering resilience and improving the quality of life. (pp. 241-254). Cham, Switzerland: Springer International Publishing.

UN-Habitat. (2013). State of the world's cities 2012/2013. UN: Kenya.

Vasey-Ellis, N. (2009). Planning for climate change in coastal Victoria. Urban Policy and Research, 27(2), 157-169.

Warnken, J. and Mosadeghi, R. (2018). Challenges of implementing integrated coastal zone management into local planning policies, a case study of Queensland, Australia. Marine Policy, 91, 75-84.

Zahran, S., Brody, S.D., Vedlitz, A., Grover, H., Miller, C. (2008). Vulnerability and capacity: Explaining local commitment to climate-change policy. Environment and Planning C: Government and Policy, 26(3), 544-562. 


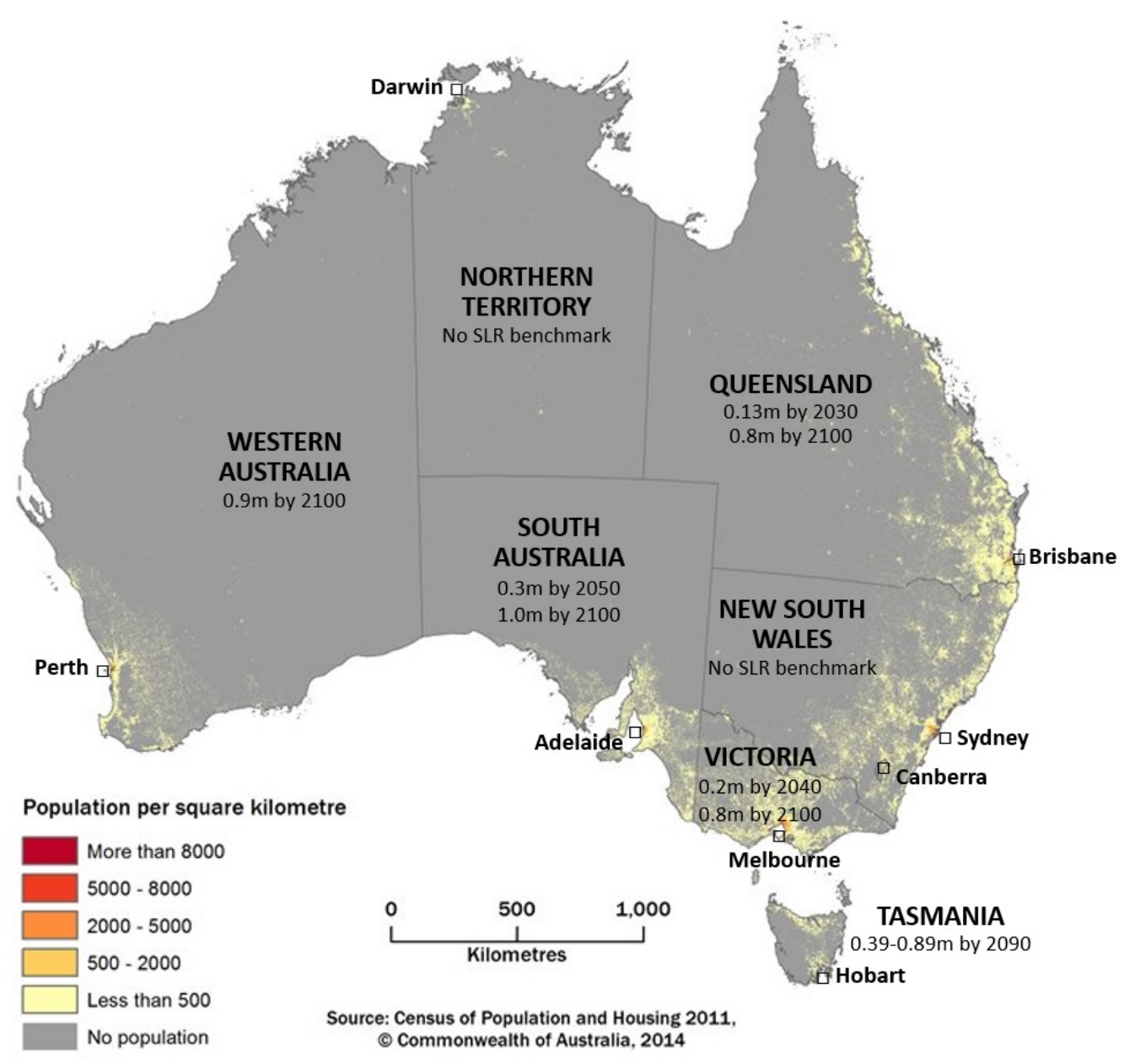

Figure 1. Australia's coastal population and SLR benchmarks of the states and territories 

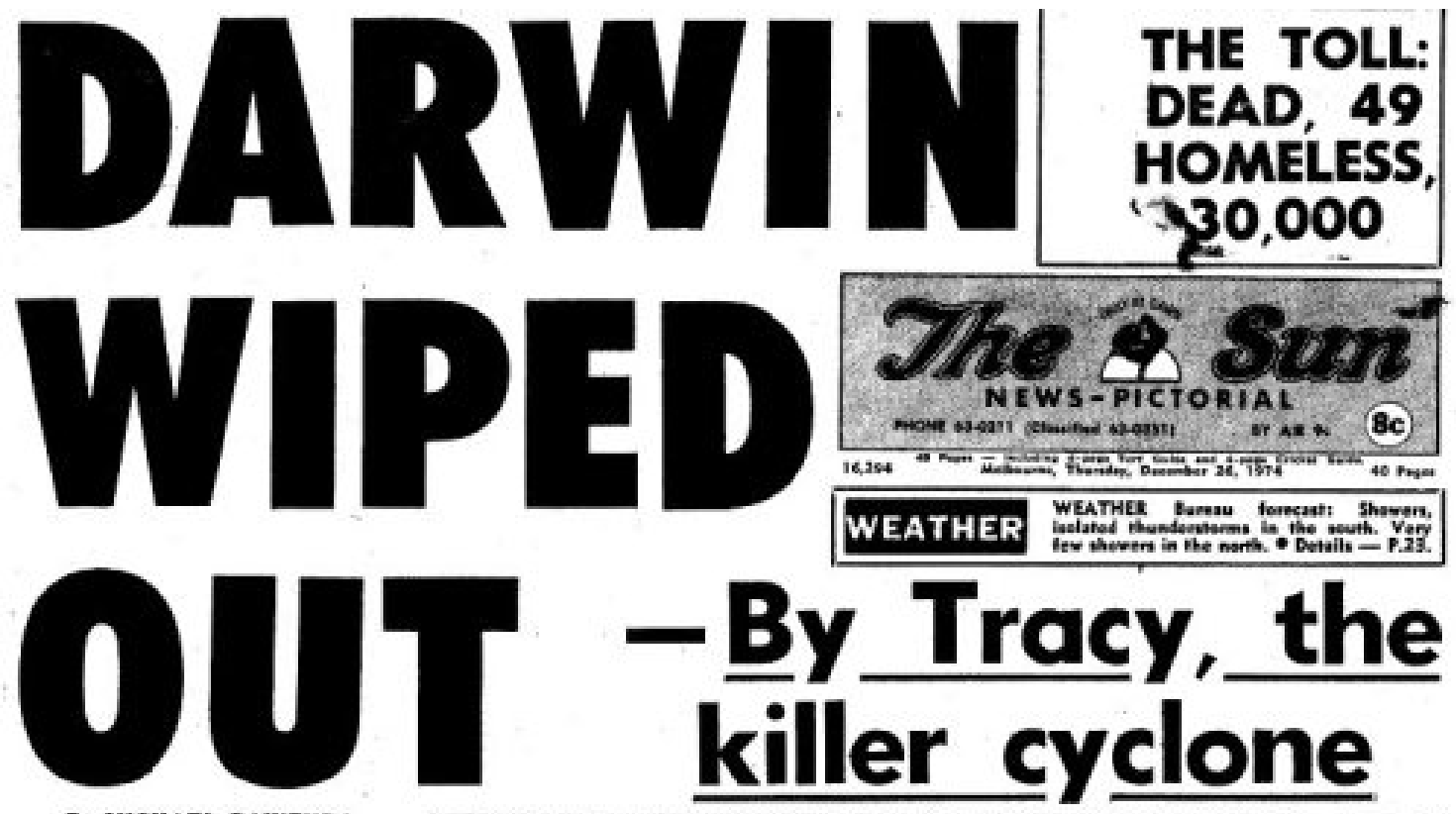

AT LEAST 49 people died in the cyclone which smashed Darwin yesterday.

Officials say the toll could reach 100 after rescuers search rubble.

Cyelone Traey has destroyed of badly damaged 95 per cent of the city.

Ornelals estimate up to 30,000 of the etty's 40,000 peogile are bomeless.

\section{7 ships}

All power is off. There is no fresh set ep.

Tracy $\div 240 \mathrm{kmh}$ (150 mph) winds sank teo silve and swept five others aground in Darwin hastopt

The elty's bespital is a wreck - with the root ripped

The hnepital patients wete taken so

The poibe station and poot afflee alvo Ait havgars and $\$$ per cent of the termina bialdings at Darwin sirport are

Ruminays are strem with rubble

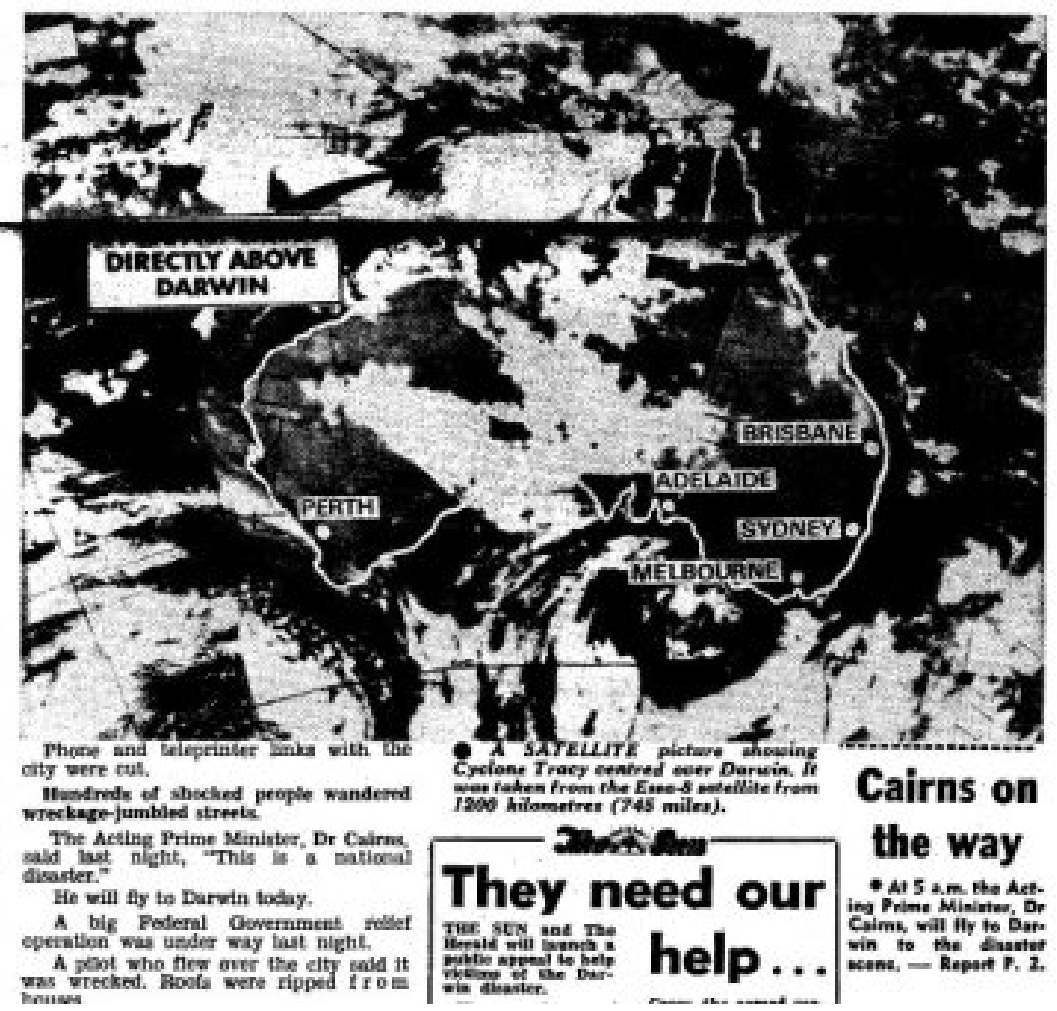

Figure 2. Front page of the Melbourne Sun, Boxing Day, 1974 
Table 1. Overview of Coastal Adaptation Risk and SLR Benchmarks in States and Territories

\begin{tabular}{|c|c|c|c|}
\hline Jurisdiction & $\begin{array}{l}\text { Population } \\
\text { (ABS, 2018) }\end{array}$ & Assets at risk (DCCEE, 2011) ${ }^{\mathrm{a}}$ & SLR Benchmark $^{\text {b }}$ \\
\hline New South Wales & $7,955,900$ & $\begin{array}{l}\text { - } 700-1,200 \text { commercial buildings ( } \$ 5-\$ 9 \text { billion) } \\
\text { - } 600-1,000 \text { light industrial buildings ( } \$ 0.8-\$ 1.1 \text { billion) } \\
\text { - Rail } \$ 0.6-\$ 1.3 \text { billion } \\
\text { - } \mathbf{4 4 , 0 0 0 - 6 8 , 0 0 0} \text { residential buildings }(\mathbf{~} \mathbf{1 4}-\mathbf{\$ 2 0} \text { billion) }\end{array}$ & - \\
\hline Victoria & $6,430,000$ & $\begin{array}{l}\text { - } \mathbf{1 , 5 0 0 - 2 , 0 0 0} \text { commercial buildings ( } \$ 8-\$ 12 \text { billion) } \\
\text { - } 600-1,000 \text { light industrial buildings }(\$ 0.5-\$ 0.8 \text { billion) } \\
\text { - } 31,000-48,000 \text { residential buildings }(\$ 8-\$ 11 \text { billion) } \\
\text { - Rail } \$ 0.1-\$ 0.5 \text { billion }\end{array}$ & $\begin{array}{l}0.2 \mathrm{~m} \text { by } 2040 \\
0.8 \mathrm{~m} \text { by } 2100\end{array}$ \\
\hline Queensland & $4,990,700$ & 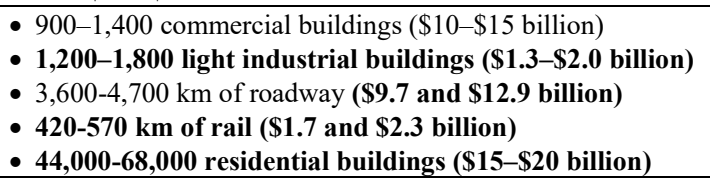 & $\begin{array}{l}0.13 \mathrm{~m} \text { by } 2030 \\
0.8 \mathrm{~m} \text { by } 2100\end{array}$ \\
\hline Western Australia & $2,591,900$ & $\begin{array}{l}\text { - } \mathbf{1 , 5 0 0}-\mathbf{2 , 1 0 0} \text { commercial buildings ( } \$ 12-\$ 17 \text { billion) } \\
\text { - } 600-900 \text { light industrial buildings }(\$ 0.7-\$ 1.1 \text { billion) } \\
\text { - } \mathbf{7 , 5 0 0 - 9 , 1 0 0 ~} \mathbf{k m} \text { of roadway ( } \$ 8.7 \text { and } \$ 11.3 \text { billion) } \\
\text { - Rail } \$ 0.1-\$ 0.5 \text { billion } \\
\text { - } 20,000-30,000 \text { residential buildings ( } \$ 5-\$ 8 \text { billion) }\end{array}$ & $0.9 \mathrm{~m}$ by 2110 \\
\hline South Australia & $1,733,500$ & $\begin{array}{l}\text { - } 900-1,500 \text { commercial buildings ( } \$ 22-\$ 27 \text { billion) } \\
\text { - } 400-1,100 \text { light industrial buildings ( } \$ 0.6-\$ 1.2 \text { billion) } \\
\text { - Rail } \$ 0.6-\$ 1.3 \text { billion } \\
\text { - } 31,000-48,000 \text { residential buildings ( } \$ \mathbf{5}-\mathbf{\$ 8} \text { billion) }\end{array}$ & $\begin{array}{l}0.3 \mathrm{~m} \text { by } 2050 \\
1 \mathrm{~m} \text { by } 2100\end{array}$ \\
\hline Tasmania & 526,700 & $\begin{array}{l}\text { - Road less than } \$ 7 \text { billion. } \\
\text { - Rail } \$ 0.6-\$ 1.3 \text { billion } \\
\text { - } 12,000-15,000 \text { residential buildings ( } \$ 4 \text { billion) }\end{array}$ & $0.39-0.89 \mathrm{~m}$ by 2090 \\
\hline Northern Territory & 246,700 & $\begin{array}{l}\text { - Road less than } \$ 7 \text { billion. } \\
\text { - Rail } \$ 0.1-\$ 0.5 \text { billion }\end{array}$ & - \\
\hline
\end{tabular}

${ }^{a}$ Number of assets at risk at 1.1 metres (high end scenario for 2100) and 2008 replacement value in AU\$, bold typeface indicates the most number of structures or replacement value at risk

${ }^{\mathrm{b}}$ For a full list of policies see Supplementary Material. 
Table 2. Structural Coastal Adaptation Measures Found in State Policies ${ }^{\mathrm{a}}$

\begin{tabular}{|c|c|c|c|}
\hline \multirow{2}{*}{ Jurisdiction } & \multicolumn{2}{|c|}{ Protection } & \multirow{2}{*}{ Accommodation } \\
\hline & Physical & Natural & \\
\hline $\begin{array}{l}\text { New South } \\
\text { Wales }\end{array}$ & - Coastal protection works & $\begin{array}{l}\text { - Protection/enhancement of } \\
\text { coastal wetlands } \\
\text { - Beach nourishment }\end{array}$ & $\begin{array}{l}\text { - Managing and minimising risks in } \\
\text { development } \\
\text { - Development setbacks } \\
\text { - Water Sensitive Urban Design }\end{array}$ \\
\hline Victoria & $\begin{array}{l}\text { - Coastal protection works in } \\
\text { areas that are considered } \\
\text { appropriate }\end{array}$ & $\begin{array}{l}\text { - Protection/enhancement of } \\
\text { coastal environment } \\
\text { - Soft engineering (e.g. dune and } \\
\text { beach nourishment and } \\
\text { restoration of mangroves and } \\
\text { seagrass beds as wave breaks or } \\
\text { buffers) }\end{array}$ & $\begin{array}{l}\text { - Consideration of climate change } \\
\text { risks in the siting, design, and } \\
\text { construction of major infrastructure } \\
\text { and dwellings } \\
\text { - Emergency management } \\
\text { - A general freeboard more than } \\
0.3 m\end{array}$ \\
\hline Queensland & $\begin{array}{l}\text { - Factor projected SLR in the } \\
\text { design and construction of } \\
\text { tidal works including } \\
\text { revetments and seawalls } \\
\text { - Coastal protection works in } \\
\text { erosion prone areas (as the } \\
\text { last resort) } \\
\text { - Infrastructure be suitable to } \\
\text { withstand or quickly and } \\
\text { cost-effectively repaired in } \\
\text { extreme weather events }\end{array}$ & $\begin{array}{l}\text { - Protection/enhancement of } \\
\text { coastal environment } \\
\text { - Beach nourishment } \\
\text { - Management of natural } \\
\text { landscapes to reduce impacts of } \\
\text { floods } \\
\text { - Green infrastructure and design } \\
\text { in combination with natural } \\
\text { defence from extreme storms } \\
\text { such as mangroves }\end{array}$ & $\begin{array}{l}\text { - Minimise/mitigate the risks to } \\
\text { development if the area cannot be } \\
\text { avoided } \\
\text { - A general freeboard more than } \\
0.3 m \\
\text { - Innovation in urban design for } \\
\text { living with the impacts of floods }\end{array}$ \\
\hline $\begin{array}{l}\text { Western } \\
\text { Australia }\end{array}$ & - Coastal protection works & $\begin{array}{l}\text { - Protection/enhancement of } \\
\text { natural coastal environment } \\
\text { - Beach nourishment, } \\
\text { replenishment, dune } \\
\text { management } \\
\text { - Coastal development setbacks } \\
\text { and shoreline stabilisation } \\
\end{array}$ & $\begin{array}{l}\text { - Accommodation of coastal impacts } \\
\text { by design and management } \\
\text { strategies } \\
\text { - Future land use and urban } \\
\text { development to minimise risks } \\
\text { - Emergency evacuation plans and } \\
\text { notification on title }\end{array}$ \\
\hline $\begin{array}{l}\text { South } \\
\text { Australia }\end{array}$ & $\begin{array}{l}\text { - Appropriate coastal } \\
\text { protection works } \\
\text { - Development not minimising } \\
\text { the structural integrity of } \\
\text { existing seawalls, levees, etc. } \\
\text { - Cost sharing models for } \\
\text { construction of coastal } \\
\text { protection structures }\end{array}$ & $\begin{array}{l}\text { - Protection/enhancement of } \\
\text { coastal environment } \\
\text { - Provide buffer areas for coastal } \\
\text { features and separate } \\
\text { development from foreshore and } \\
\text { sensitive coastal areas } \\
\text { - Soft engineering, beach } \\
\text { nourishment, replenishment, and } \\
\text { dune management } \\
\text { - Living shoreline (e.g. using } \\
\text { oyster beds) as an alternative to } \\
\text { seawalls } \\
\end{array}$ & $\begin{array}{l}\text { - Hazard risk minimisation in new } \\
\text { and existing development } \\
\text { - Development setbacks } \\
\text { - Raising development } \\
\text { - Emergency management }\end{array}$ \\
\hline Tasmania & $\begin{array}{l}\text { - Coastal engineering } \\
\text { measures }\end{array}$ & $\begin{array}{l}\text { Protection/enhancement of } \\
\text { coastal environment by } \\
\text { minimising the need for } \\
\text { engineering works, avoiding } \\
\text { impacts on sensitive areas, etc. } \\
\text { - Contain urban development to } \\
\text { protect ecological values } \\
\text { - Beach nourishment/ } \\
\text { replenishment }\end{array}$ & $\begin{array}{l}\text { - Development subject to risk from } \\
\text { coastal erosion and inundation is } \\
\text { appropriately located and managed } \\
\text { - Future land use and urban } \\
\text { development to minimise risks } \\
\text { (from flooding, SLR, storm surge } \\
\text { inundation and shoreline recession) } \\
\text { - Ensure best practice construction } \\
\text { and design techniques are } \\
\text { implemented } \\
\text { - A general freeboard more than } \\
0.3 m\end{array}$ \\
\hline $\begin{array}{l}\text { Northern } \\
\text { Territory }\end{array}$ & $\begin{array}{l}\text { Seawall and appropriate } \\
\text { coastal protection for } \\
\text { residential and commercial } \\
\text { areas }\end{array}$ & $\begin{array}{l}\text { - Rehabilitation of coastal } \\
\text { wetlands }\end{array}$ & $\begin{array}{l}\text { - Locate new development above } 1 \% \\
\text { AEP flood and storm tide events } \\
\text { - Adopt design response } \\
\text { - Minimum floor levels } 0.3 \text { above } \\
\text { defined flood levels }\end{array}$ \\
\hline
\end{tabular}

${ }^{a}$ Italic text indicates the responsibilities/strategies related to addressing the impacts of flooding (not specifically coastal impacts). The important differences between the jurisdictions are highlighted in bold characters. 
Table 3. Non-Structural Coastal Adaptation Measures Found in State Policies ${ }^{\mathrm{a}}$

\begin{tabular}{|c|c|c|c|}
\hline \multirow{2}{*}{ Jurisdiction } & \multicolumn{2}{|c|}{ Planning } & \multirow{2}{*}{ Other Non-Structural Measures } \\
\hline & Planned/Managed Retreat & Prohibition of Development & \\
\hline $\begin{array}{l}\text { New South } \\
\text { Wales }\end{array}$ & $\begin{array}{l}\text { Landward migration of } \\
\text { wetlands }\end{array}$ & $\begin{array}{l}\text { - Limit development in high } \\
\text { risk areas (unless risk } \\
\text { reduction measures are } \\
\text { met) }\end{array}$ & $\begin{array}{l}\text { - Development of Coastal Zone Emergency } \\
\text { Subplan and Coastal Management } \\
\text { Manual } \\
\text { - Establishment of NSW Coastal Council } \\
\text { - Hazard mapping } \\
\text { - Identifying roles and responsibilities } \\
\text { - Research } \\
\text { - Education and training } \\
\text { - Emergency management }\end{array}$ \\
\hline Victoria & $\begin{array}{l}\text { - Planned retreat in } \\
\text { vulnerable areas and } \\
\text { removal/relocation of } \\
\text { assets } \\
\text { - Removal of levee banks } \\
\text { and other artificial } \\
\text { structures to allow for } \\
\text { wetland migration/retreat }\end{array}$ & $\begin{array}{l}\text { - Identify a clear settlement } \\
\text { boundary around coastal } \\
\text { settlements } \\
\text { - Avoid development in } \\
\text { low-lying coastal areas }\end{array}$ & $\begin{array}{l}\text { - Consideration of climate change impacts in } \\
\text { decision making } \\
\text { - Preparation of climate change strategy and } \\
\text { adaptation plans } \\
\text { - Establishment of Victorian Marine and } \\
\text { Coastal Council, Victorian Coastal } \\
\text { Strategy, Coastal Action Plans, and } \\
\text { management plans } \\
\text { - Identification of at-risk areas using the best } \\
\text { available climate science, risk assessment } \\
\text { and coastal hazard mapping } \\
\text { - Coordinated and integrated land use } \\
\text { planning } \\
\text { - Coastal inundation datasets, partnerships } \\
\text { with Regional Coastal Boards } \\
\text { - Review and update planning benchmarks } \\
\text { - Financial mechanisms (e.g. charges and } \\
\text { levies for coastal protection works) } \\
\text { - Community engagement } \\
\text { - Identifying roles and responsibilities } \\
\text { - Planning for emergencies (community-based } \\
\text { emergency management) } \\
\text { - Increased collaboration } \\
\text { - Insurance and risk sharing }\end{array}$ \\
\hline Queensland & $\begin{array}{l}\text { - Retreat and relocation of } \\
\text { development and } \\
\text { infrastructure } \\
\text { - Landward retreat of } \\
\text { coastal habitats }\end{array}$ & $\begin{array}{l}\text { - Avoid development and } \\
\text { infrastructure on high risk } \\
\text { coastal land } \\
\text { - Development does not } \\
\text { involve reclamation of land } \\
\text { below tidal waters }\end{array}$ & $\begin{array}{l}\text { - Development of Coastal Hazard } \\
\text { Adaptation Study } \\
\text { - Awareness raising } \\
\text { - Assessment of impacts and risk } \\
\text { - Flood mapping and risk management } \\
\text { - Integration of climate change into } \\
\text { governance and policy } \\
\text { - Research and development } \\
\text { - Development of plans } \\
\text { - Allocation of resources } \\
\text { - Identifying roles and responsibilities } \\
\text { - Communication of the benefits of adaptation } \\
\text { - Emergency and disaster management } \\
\text { - (including early warning systems) } \\
\text { - Enhancing adaptive capacity of communities }\end{array}$ \\
\hline $\begin{array}{l}\text { Western } \\
\text { Australia }\end{array}$ & $\begin{array}{l}\text { - Relocation/removal of } \\
\text { assets in high risk areas } \\
\text { - Applying easements or } \\
\text { planning zones to allow } \\
\text { rolling change of land use } \\
\text { - Retain public coastal } \\
\text { land in public ownership } \\
\text { - Leaving assets } \\
\text { unprotected } \\
\text { - Taking of land (including } \\
\text { taking by agreement of } \\
\text { compulsory acquisition) }\end{array}$ & $\begin{array}{l}\text { Avoid new development in } \\
\text { areas affected by coastal } \\
\text { hazards } \\
\text { - Locate new greenfield } \\
\text { development landward }\end{array}$ & $\begin{array}{l}\text { - Emergency management } \\
\text { - Identification of roles and responsibilities } \\
\text { - Hazard mapping and modelling } \\
\text { - Risk management } \\
\text { - Community engagement } \\
\text { - Coastal adaptation and protection grant } \\
\text { scheme for coastal monitoring and data } \\
\text { collection } \\
\text { - Ensuring funding based on coast benefit } \\
\text { analysis } \\
\text { - Raising awareness }\end{array}$ \\
\hline
\end{tabular}




\begin{tabular}{|c|c|c|c|}
\hline \multirow{2}{*}{ Jurisdiction } & \multicolumn{2}{|c|}{ Planning } & \multirow{2}{*}{ Other Non-Structural Measures } \\
\hline & Planned/Managed Retreat & Prohibition of Development & \\
\hline $\begin{array}{l}\text { South } \\
\text { Australia }\end{array}$ & $\begin{array}{l}\text { - Landward } \\
\text { migration/relocation of } \\
\text { development and } \\
\text { abandonment of } \\
\text { infrastructure } \\
\text { - Land acquisition } \\
\text { - Local government power } \\
\text { for compulsory land } \\
\text { acquisition for mitigation } \\
\text { of floods } \\
\text { - Allow for SLR induced } \\
\text { retreat of tidal ecosystems }\end{array}$ & $\begin{array}{l}\text { - Avoid development in high } \\
\text { risk areas } \\
\text { - Limit development in } \\
\text { coastal areas of } \\
\text { conservation }\end{array}$ & $\begin{array}{l}\text { - Development of a Coastal Management } \\
\text { Plan and responsibilities of the Coast } \\
\text { Protection Board } \\
\text { - Coastal Rotation Grants (e.g. grants for flood } \\
\text { embankments) } \\
\text { - Mapping and modelling of risks } \\
\text { - Embedding climate risks in planning } \\
\text { - Community engagement } \\
\text { - Emergency management } \\
\text { - Developing local adaptation plans } \\
\text { - Development of Regional Climate Change } \\
\text { - Adaptation Plans } \\
\text { - Warning and evacuation systems } \\
\text { - Monitoring of impacts } \\
\text { education and awareness raising, } \\
\text { encouraging behavioural change (e.g. } \\
\text { requiring home buyers to be informed about } \\
\text { risks in the Eyre Peninsula climate } \\
\text { adaptation plan) }\end{array}$ \\
\hline Tasmania & $\begin{array}{l}\text { - Retraction of existing } \\
\text { settlement locations and } \\
\text { relocation of infrastructure } \\
\text { - Landward retreat of } \\
\text { coastal habitats }\end{array}$ & $\begin{array}{l}\text { Prohibit works and } \\
\text { development in coastal } \\
\text { inundation and erosion } \\
\text { areas } \\
\text { - Limit the expansion of } \\
\text { urban development in } \\
\text { coastal zone }\end{array}$ & $\begin{array}{l}\text { - Awareness raising (including online } \\
\text { information) } \\
\text { - Public participation } \\
\text { - Hazard and inundation mapping and } \\
\text { overlays } \\
\text { - Early warning and alerts } \\
\text { - Integration of climate change into } \\
\text { governance and decision making } \\
\text { - Coastal hazard management } \\
\text { - Identification of management authorities }\end{array}$ \\
\hline $\begin{array}{l}\text { Northern } \\
\text { Territory }\end{array}$ & & $\begin{array}{l}\text { - Avoid development of land } \\
\text { affected by a } 1 \% \text { AEP } \\
\text { flood or storm surge event } \\
\text { - Limit development in high } \\
\text { risk areas to open space, } \\
\text { recreation, non-essential } \\
\text { public facilities or } \\
\text { industrial uses } \\
\end{array}$ & $\begin{array}{l}\text { - Emergency management } \\
\text { - Warning and forecasting } \\
\text { - Identifying roles and responsibilities } \\
\text { - Hazard mapping }\end{array}$ \\
\hline
\end{tabular}

${ }^{a}$ Italic text indicates the responsibilities/strategies related to addressing the impacts of flooding. The important differences between the jurisdictions are highlighted in bold characters. 
Table 4. Assessment of Australian Coastal Adaptation in States and Territories

\begin{tabular}{|c|c|c|c|c|c|c|c|c|}
\hline \multicolumn{2}{|c|}{ Assessment Criteria } & NSW & VIC & QLD & WA & SA & TAS & NT \\
\hline \multicolumn{2}{|c|}{$\begin{array}{l}\text { Level of Adaptation in State } \\
\text { Legislation and Policy }\end{array}$} & 2 & 3 & 3 & 1 & 2 & 1 & 0 \\
\hline \multicolumn{2}{|c|}{ SLR Benchmark } & 0 & 3 & 3 & 2 & 3 & 1 & 0 \\
\hline \multirow[t]{3}{*}{$\begin{array}{l}\text { Structural } \\
\text { Measures }\end{array}$} & $\begin{array}{l}\text { Physical } \\
\text { Protection } \\
\end{array}$ & 3 & 3 & 3 & 3 & 3 & 3 & 3 \\
\hline & $\begin{array}{l}\text { Natural } \\
\text { Protection }\end{array}$ & 2 & 2 & 2 & 2 & 3 & 2 & 2 \\
\hline & Accommodate & 3 & 3 & 3 & 3 & 3 & 3 & 3 \\
\hline \multirow{3}{*}{$\begin{array}{l}\text { Non- } \\
\text { Structural } \\
\text { Measures }\end{array}$} & Retreat & 0 & 2 & 1 & 3 & 3 & 1 & 0 \\
\hline & Avoid & 2 & 3 & 2 & 3 & 2 & 2 & 3 \\
\hline & Other & 2 & 2 & 3 & 1 & 2 & 1 & 0 \\
\hline \multirow{2}{*}{\multicolumn{9}{|c|}{\begin{tabular}{|c|c|}
$\mathbf{2 1}$ & $\mathbf{2 0}$ \\
Scoring System
\end{tabular}}} \\
\hline & & & & & & & & \\
\hline 0 & \multicolumn{8}{|c|}{ No evidence or largely absent } \\
\hline 1 & \multicolumn{8}{|c|}{ Acknowledged/mentioned, but no details provided } \\
\hline 2 & \multicolumn{8}{|c|}{ Discussed with some level of detail } \\
\hline 3 & \multicolumn{8}{|c|}{ Details provided } \\
\hline
\end{tabular}




\section{Supplementary Material to "Planning for a Different Kind of Sea Change: Lessons from Australia for Sea Level Rise and Coastal Flooding"}

Table 1. Overview of Coastal Adaptation Legislation and Policy in Australian Coastal States and Territories ${ }^{\mathrm{a}}$

\begin{tabular}{|c|c|c|c|c|c|c|c|}
\hline & New South Wales & Victoria & Queensland & Western Australia & South Australia & Tasmania & Northern Territory \\
\hline 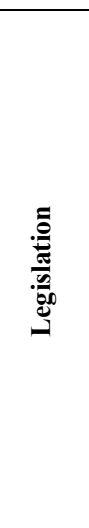 & 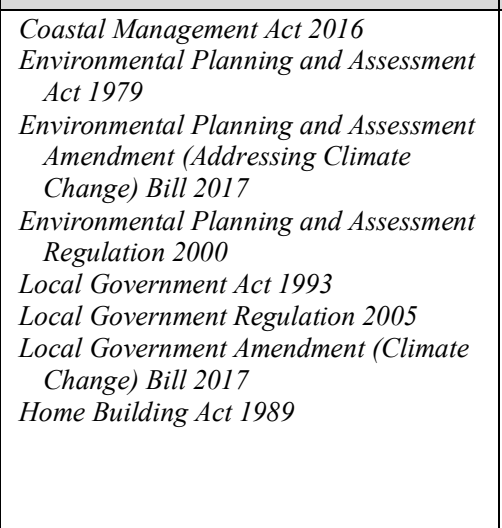 & 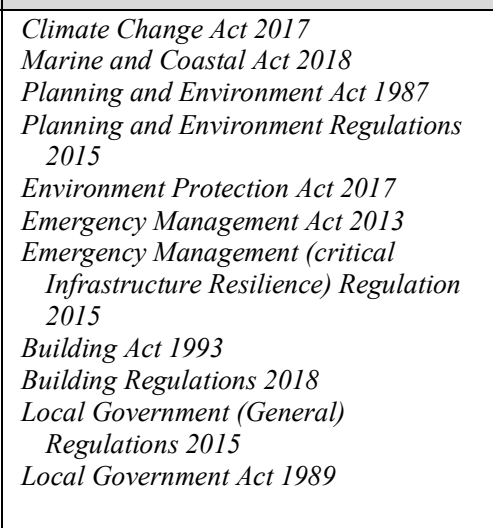 & 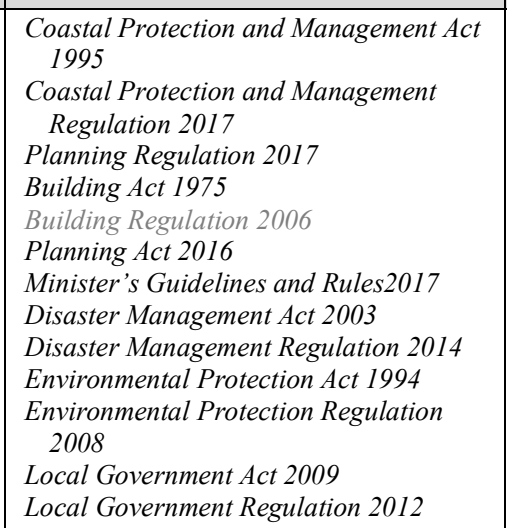 & 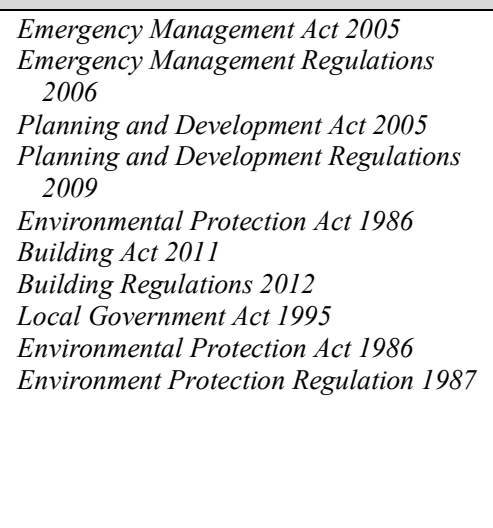 & 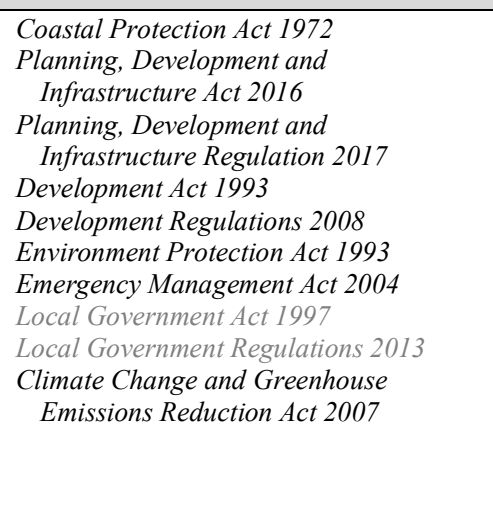 & \begin{tabular}{|l|} 
Local Government Act 1993 \\
Building AAt 2016 \\
Building Regulations 2017 \\
Tasmania Land Lse Planning and \\
Approvals Act1993
\end{tabular} & $\begin{array}{l}\text { Local Government Act (as of 2017) } \\
\text { Planning Act 1999 } \\
\text { Emergency Management Act 2013 } \\
\text { Building Act 1993 } \\
\text { Building Regulations (as of July 2016) }\end{array}$ \\
\hline 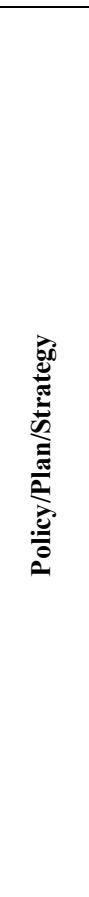 & 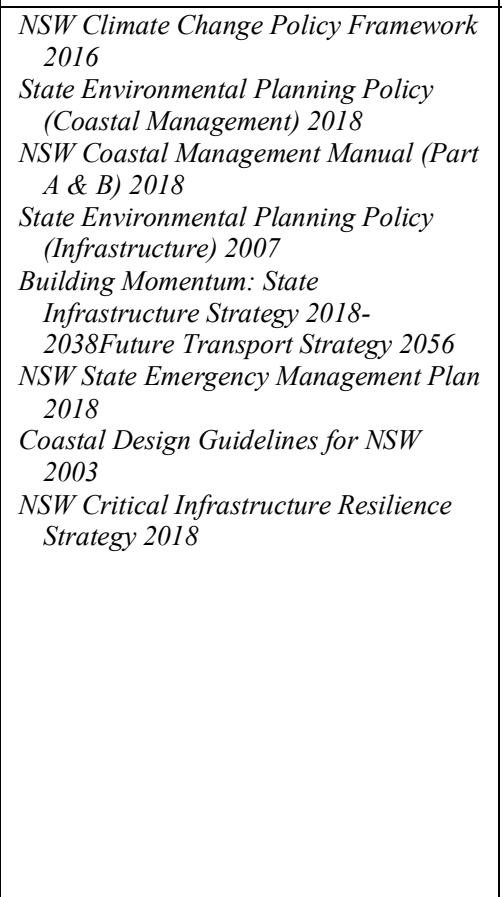 & 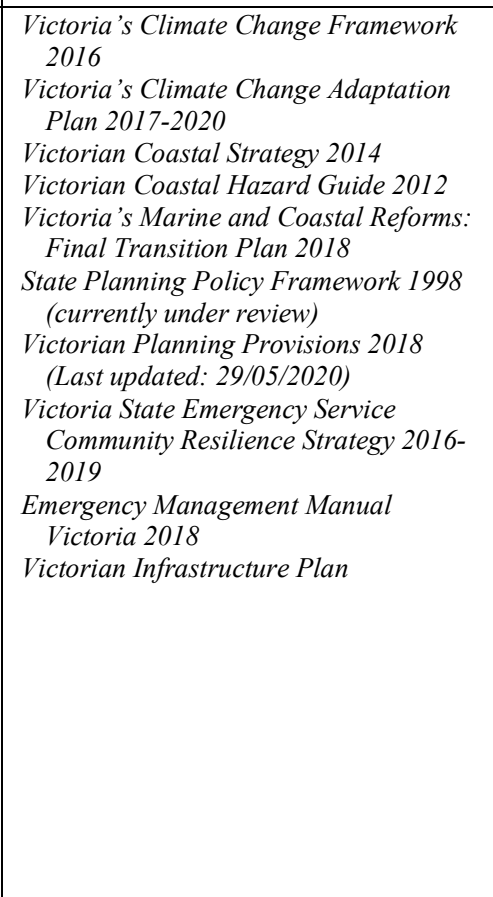 & 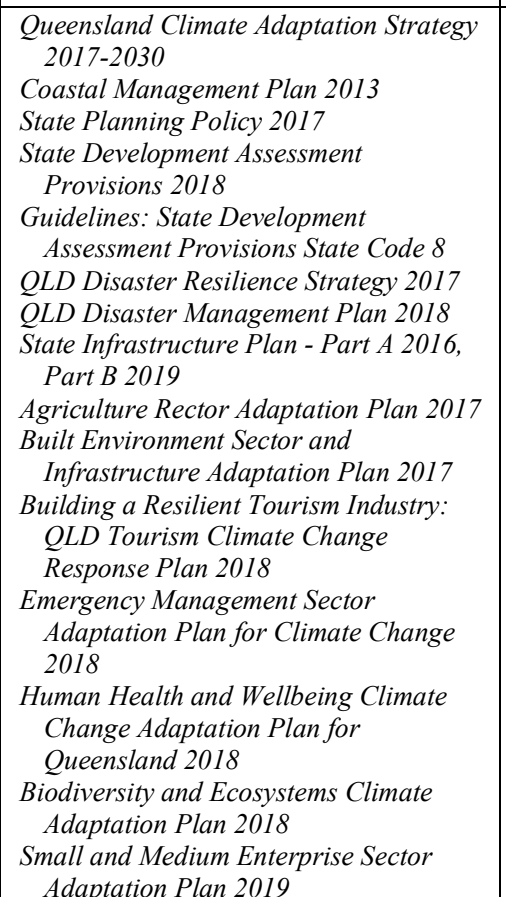 & 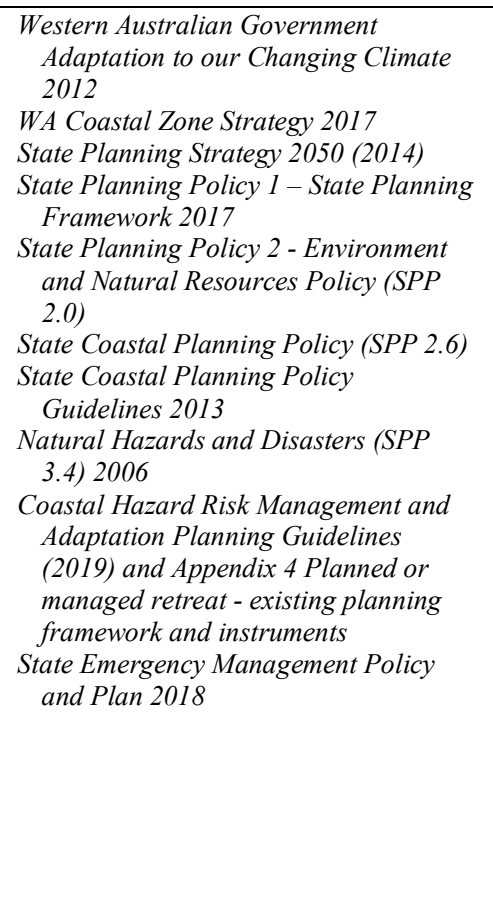 & 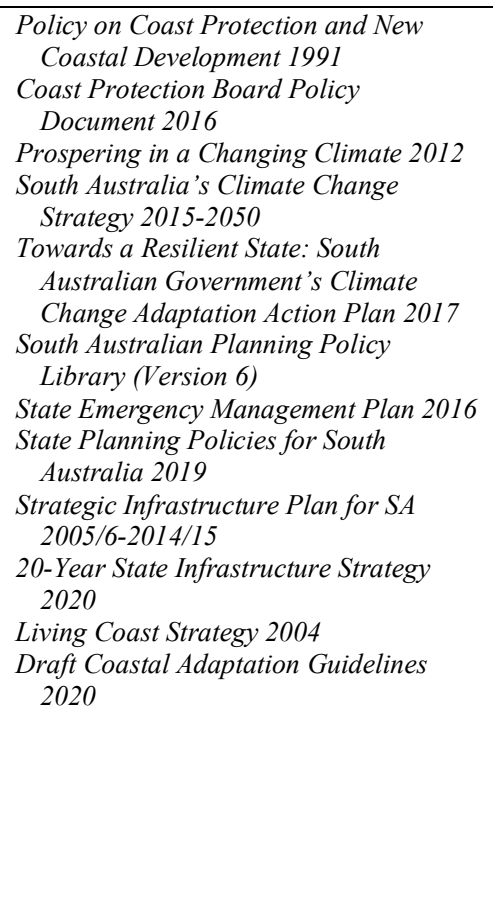 & 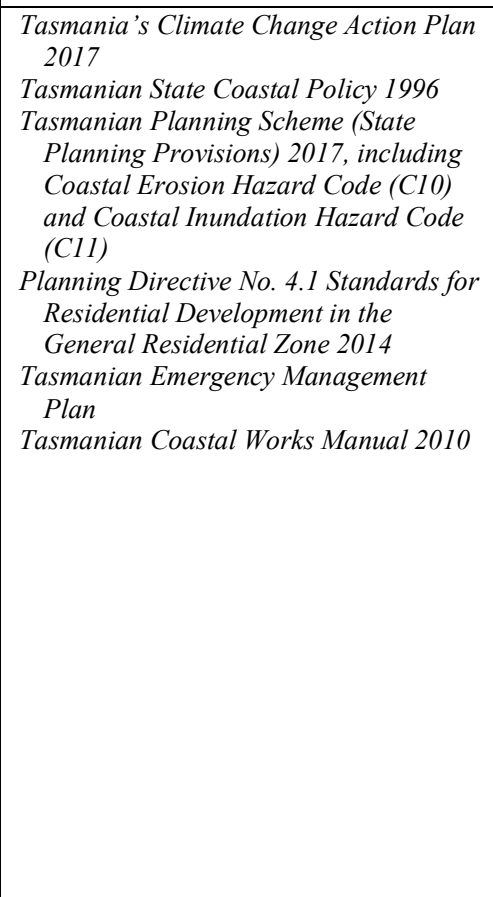 & $\begin{array}{l}\text { Northern Territory Climate Change } \\
\text { Policy 2009 } \\
\text { Climate Change Discussion Paper } 2018 \\
\text { Northern Territory (NT) Planning } \\
\text { Scheme } \\
10 \text { Year Infrastructure Plan 2019-2028 } \\
\text { Territory Emergency Plan 2019 } \\
\text { Northern Territory All Hazards } \\
\text { Emergency Management } \\
\text { Arrangements (2011) } \\
\text { Coastal and Marine Management } \\
\text { Strategy 2019-2019 }\end{array}$ \\
\hline 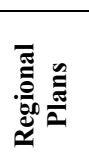 & $\begin{array}{l}6 \text { coastal regional plans including } 1 \\
\text { Metropolitan Plan }\end{array}$ & \begin{tabular}{|l}
7 regional plans (including 3 Regional \\
Coastal Plans, 3 coastal Regional Growth \\
Plans, and 1 Metropolitan Plan)
\end{tabular} & 7 coastal regional plans & $\begin{array}{l}12 \text { regional plans: } 8 \text { Regional Planning } \\
\text { and Infrastructure Framework (coastal } \\
\text { PIFs), } 3 \text { Region Schemes, and } 1 \\
\text { Metropolitan Strategy }\end{array}$ & $\begin{array}{l}18 \text { coastal regional plans: } 10 \text { Regional } \\
\text { Adaptation Plans, 6 Regional Plans (land } \\
\text { use, RPs), } 1 \text { Metropolitan Plan, } 1 \text { Coastal } \\
\text { Strategy }\end{array}$ & \begin{tabular}{|l}
3 coastal Regional Land Use Planning \\
Frameworks \\
Northern Tasmania Regional Land Use \\
Strategy (June 2018)
\end{tabular} & $\begin{array}{l}\text { Darwin Regional Land Use Plan } 2015 \\
\text { Darwin Regional Transport Plan } 2018\end{array}$ \\
\hline
\end{tabular}




\begin{tabular}{|c|c|c|c|c|c|c|c|}
\hline & New South Wales & Victoria & Queensland & Western Australia & South Australia & Tasmania & Northern Territory \\
\hline 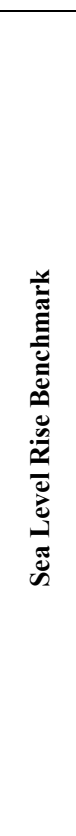 & $\begin{array}{l}\text { No State-wide projections and new } \\
\text { reform delegate the task to local councils }\end{array}$ & 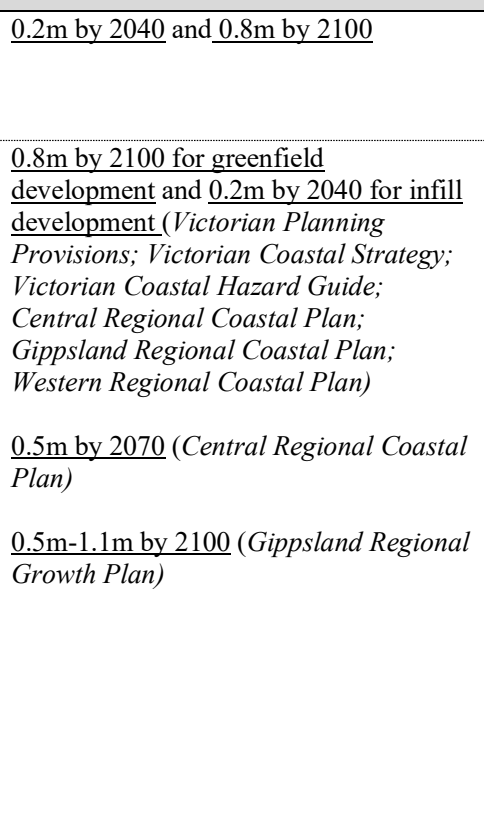 & 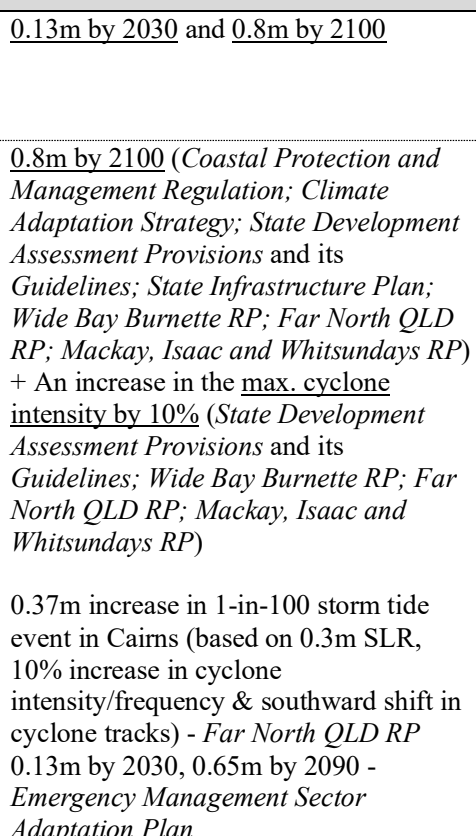 & $\begin{array}{l}\text { Not less than } 0.9 \mathrm{~m} \text { by } 2110 \\
\\
0.9 \mathrm{~m} \text { by } 2110 \text { (over } 100 \text { years) (State } \\
\text { Coostal lianning Policy, WA Coastal } \\
\text { Zone Strategy, Coastal Hazard Risk } \\
\text { Management and Adaptation Planning } \\
\text { Guidelines) }\end{array}$ & 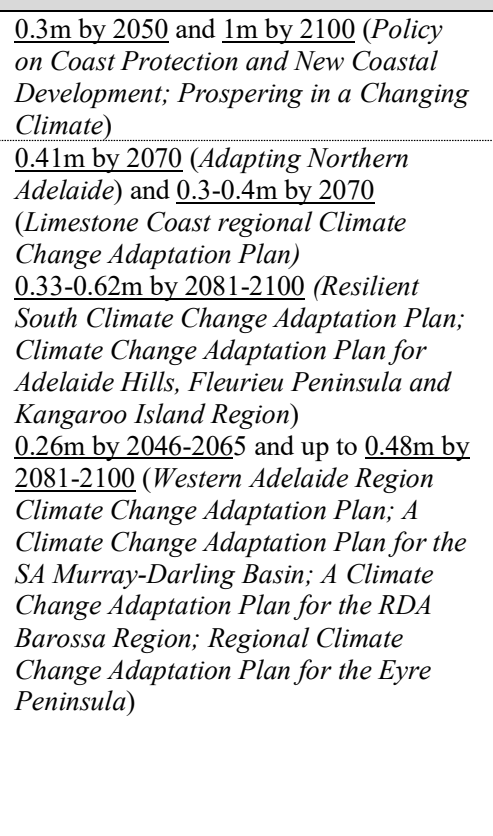 & $\begin{array}{l}\text { 0.39-0.89m by } 2090 \text { (only mentioned in } \\
\text { Tasmania's Climate Action Plan) }\end{array}$ & $\begin{array}{l}0.65 \mathrm{~m} \text { to } 0.87 \mathrm{~m} \text { above } 2005 \text { levels by } \\
2100 \text { (mentioned in the Climate Change } \\
\text { Discussion Paper } 2019 \text { only) }\end{array}$ \\
\hline D. & 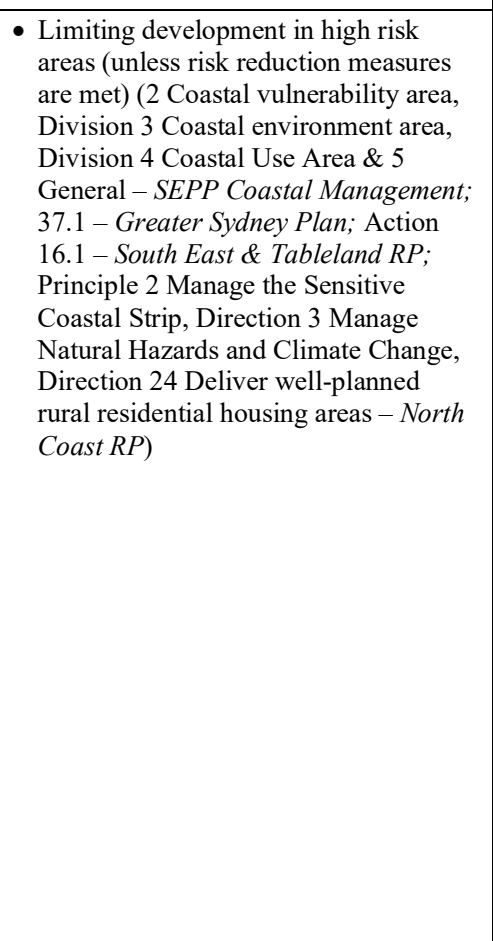 & 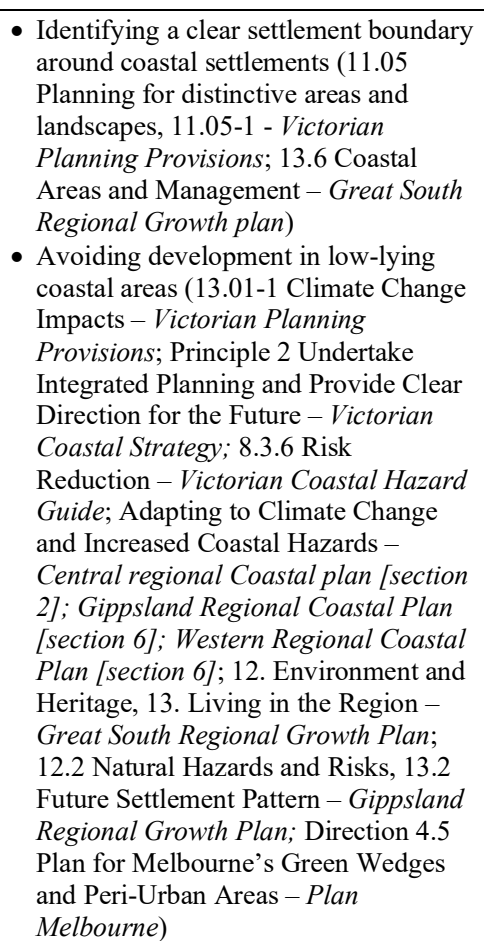 & 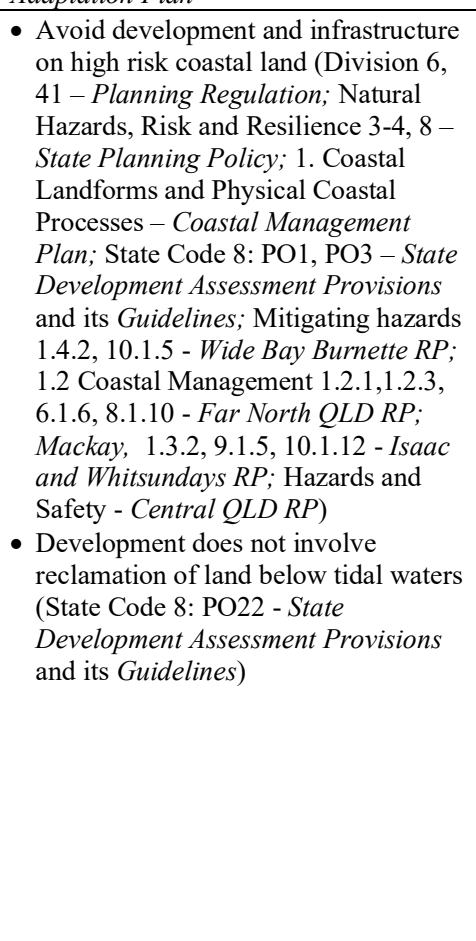 & $\begin{array}{l}\text { - Avoid new development in areas } \\
\text { affected by coastal hazards (5.6 } \\
\text { Coastal hazard risk management and } \\
\text { adaptation planning - State Coastal } \\
\text { Planning Policy; State Coastal } \\
\text { Planning Policy Guidelines; Coastal } \\
\text { Hazard Risk Management and } \\
\text { Addaptation Planning Guidelines; } 4.4 \\
\text { Urban Consolidation Principles - } \\
\text { Perth hand Peel @3.5m; - } \\
\text { Development Issues, Action C- } \\
\text { Pilbara PIF; 3.3.4 Coastal } \\
\text { Enironment - Kimberley Regional } \\
\text { PIF) } \\
\text { - Locate new greenfield development } \\
\text { landward (State Coastal Planning } \\
\text { Policy Guidelines) }\end{array}$ & 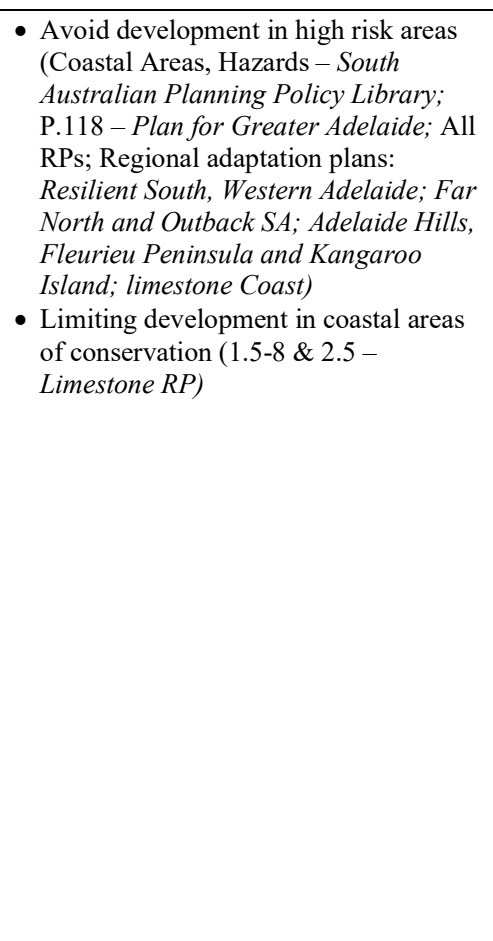 & 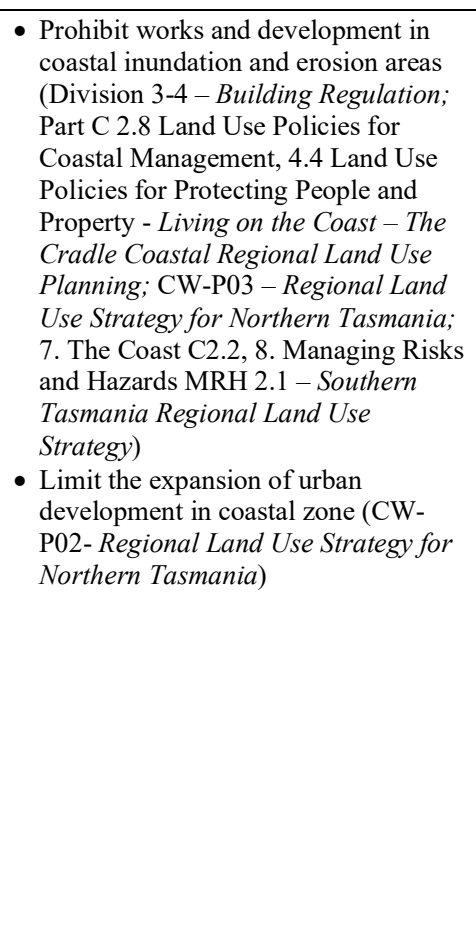 & $\begin{array}{l}\text { - Avoid development of land affected by } \\
\text { a } 1 \% \text { AEP flood or storm surge event } \\
\text { (NT Planning Scheme; Natural } \\
\text { Hazards Risks - Darwin Regional } \\
\text { Land Use Plan) } \\
\text { - Limiting development in high risk } \\
\text { areas to open space, recreation, non- } \\
\text { essential public facilities or industrial } \\
\text { uses (6.14 Land Subject to Flooding } \\
\text { and Storm Surge - NT Planning } \\
\text { Scheme) }\end{array}$ \\
\hline
\end{tabular}




\begin{tabular}{|c|c|c|c|c|c|c|c|}
\hline & New South Wales & Victoria & Queensland & Western Australia & South Australia & Tasmania & Northern Territory \\
\hline 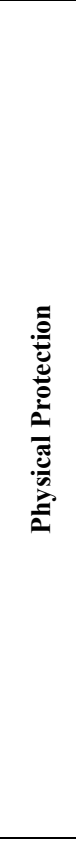 & 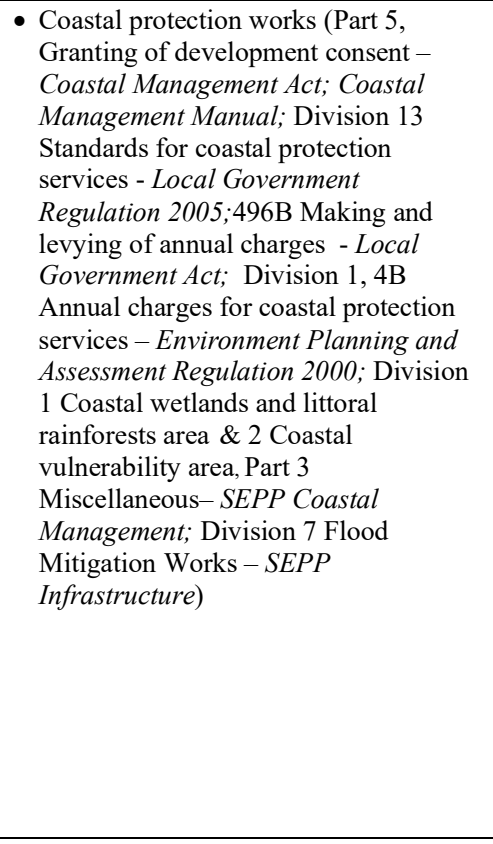 & 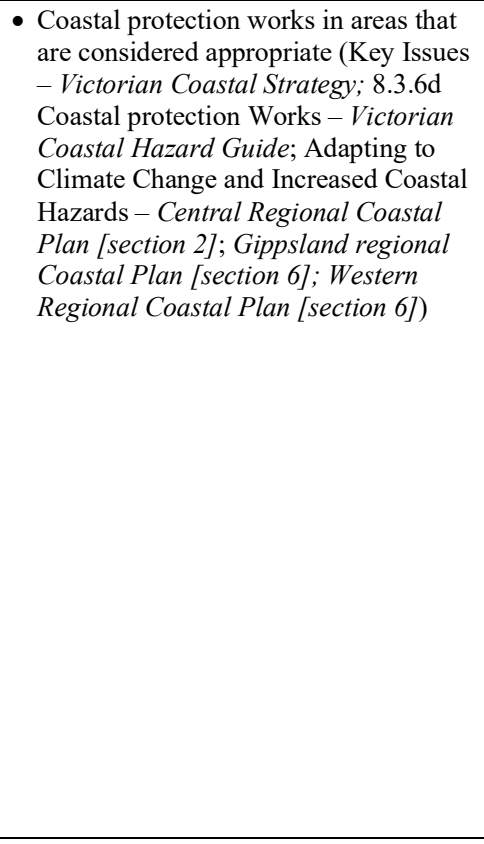 & 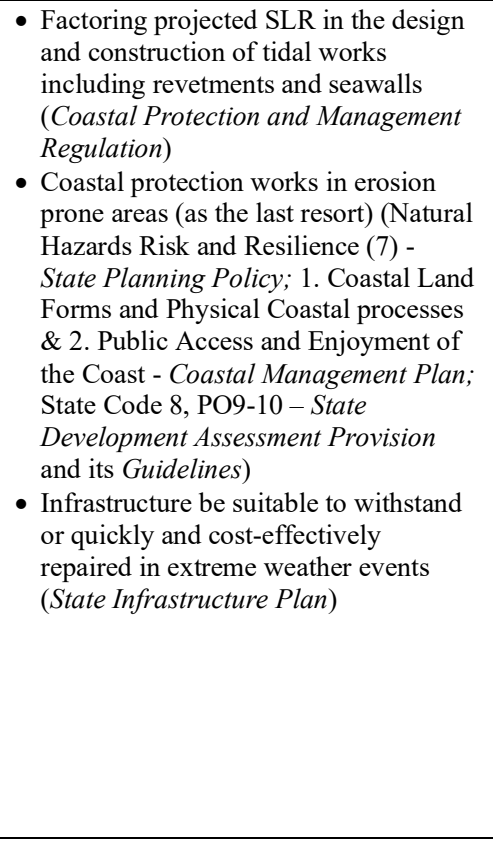 & 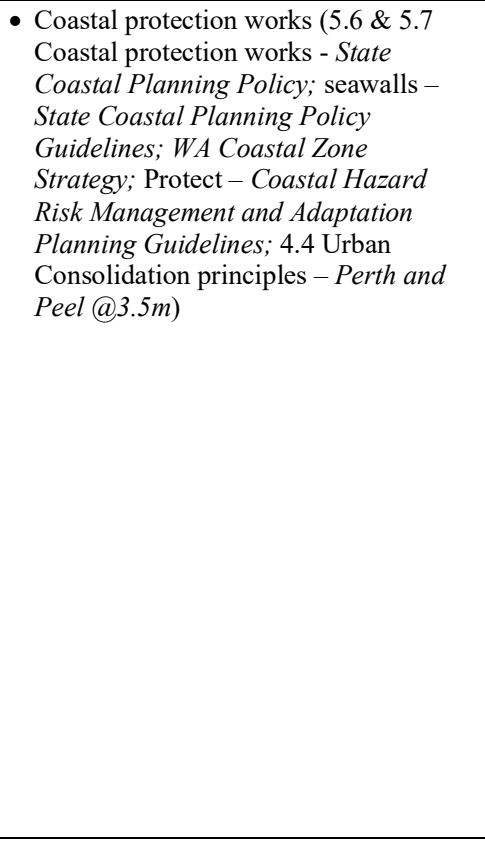 & 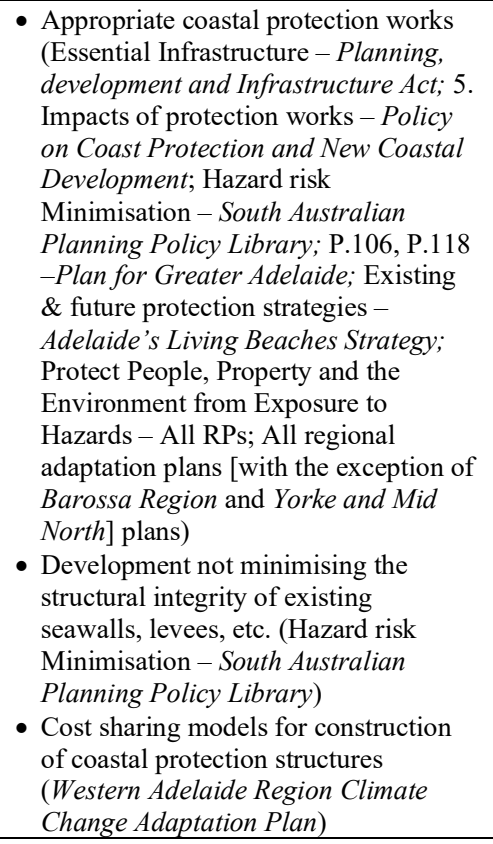 & $\begin{array}{l}\text { - Coastal engineering measures } \\
\text { (Tasmanian Coastal Works Manual } \\
\text { [non-statutory]) }\end{array}$ & $\begin{array}{l}\text { - Seawall and appropriate coastal } \\
\text { protection for residential and } \\
\text { commercial areas }(14.1 .1 .1 \text { Darwin City } \\
\text { Waterfront Planning Principles and } \\
\text { Area Plan, 14.1.3 Frances Bay } \\
\text { Planning Principles - NT Planning } \\
\text { Scheme; Protection of Darwin } \\
\text { Foreshore from Erosion - } 10 \text { Year } \\
\text { Infrastructure Plan) }\end{array}$ \\
\hline 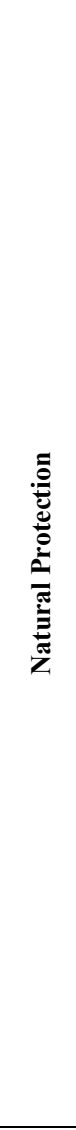 & 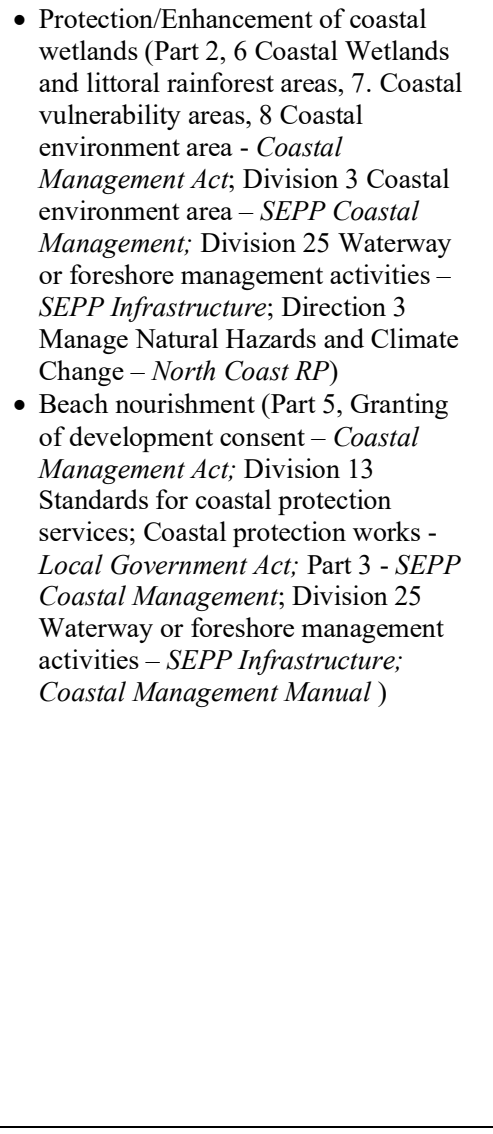 & 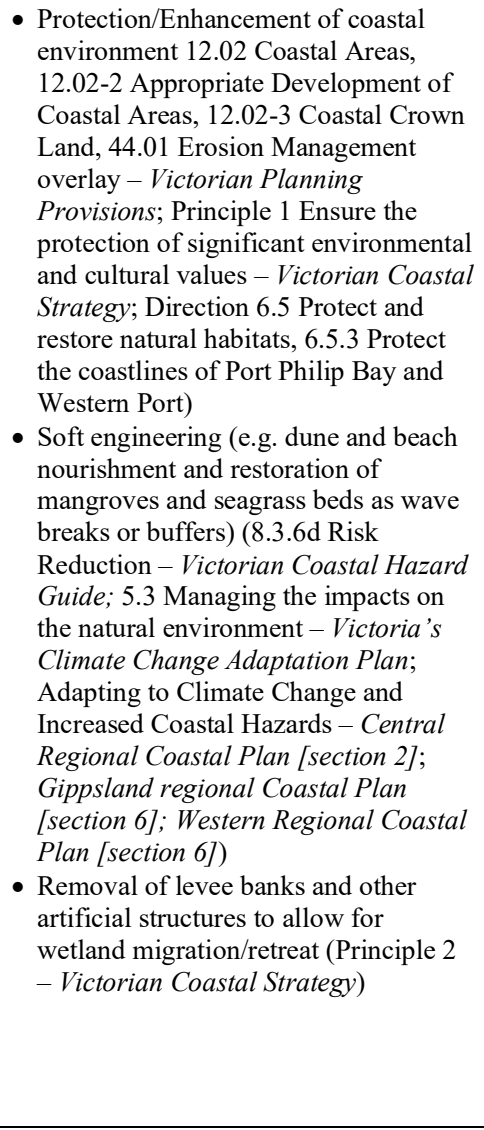 & 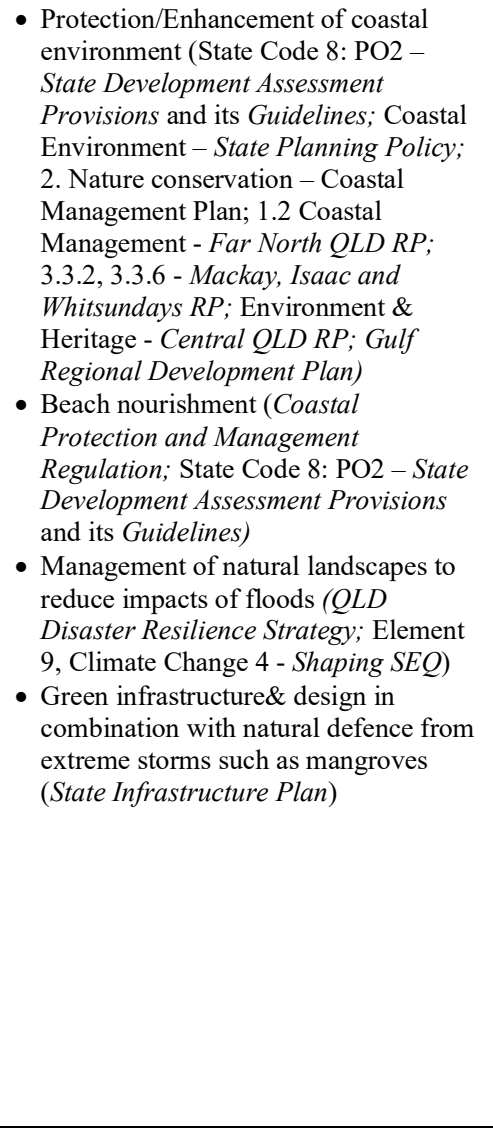 & 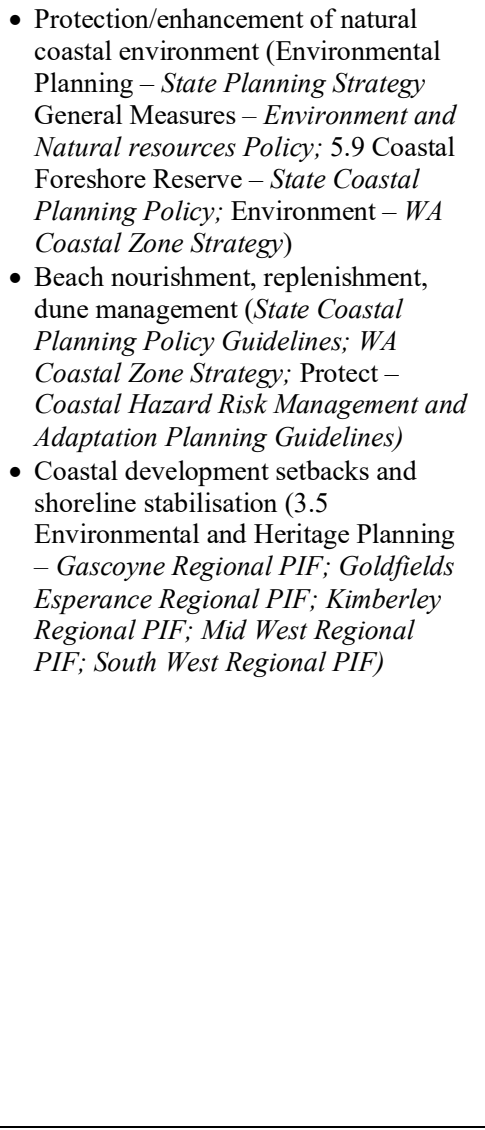 & 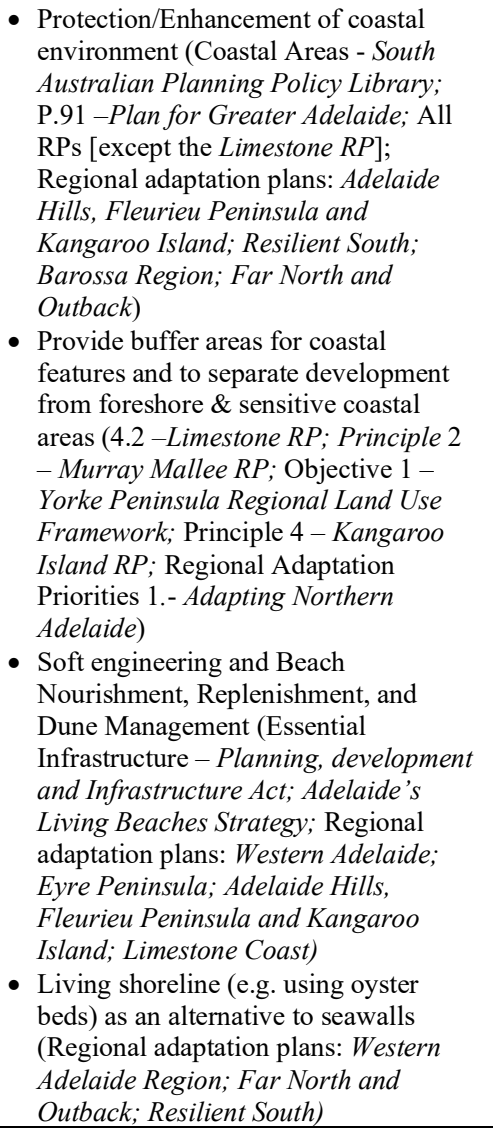 & 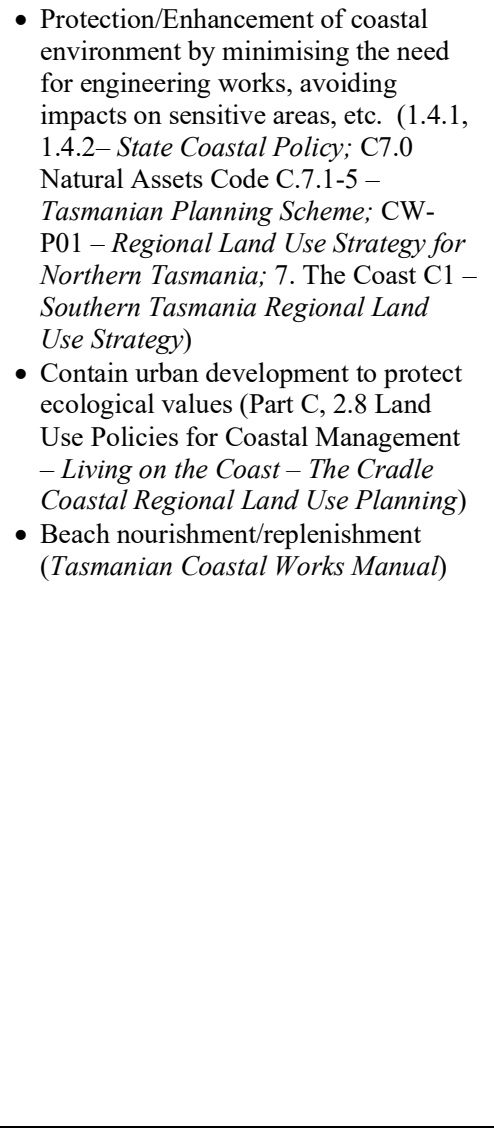 & $\begin{array}{l}- \text { Rehabilitation of coastal wetlands } \\
\text { (Target } 40-N T \text { Climate Change } \\
\text { Policy) }\end{array}$ \\
\hline
\end{tabular}




\begin{tabular}{|c|c|c|c|c|c|c|c|}
\hline & New South Wales & Victoria & Queensland & Western Australia & South Australia & Tasmania & Northern Territory \\
\hline & $\begin{array}{l}\text { - Managing and minimising risks in } \\
\text { development (Division } 4 \text { Coastal Use } \\
\text { Area \& } 5 \text { General - SEPP Coastal } \\
\text { Management; } 16.1 \text { - South East and } \\
\text { Tableland RP, Direction } 3 \text { Manage } \\
\text { Natural Hazards and Climate Change - } \\
\text { North Coast RP) } \\
\text { - Development sebacks (Part } 2 \text { - } \\
\text { Coastal Design Guidelines for NSW) } \\
\text { - Water Sensitive Urban Design (Part2 } \\
\text { Coastal Zone and Management } \\
\text { Objectives - Coastal Management } \\
\text { Act) }\end{array}$ & 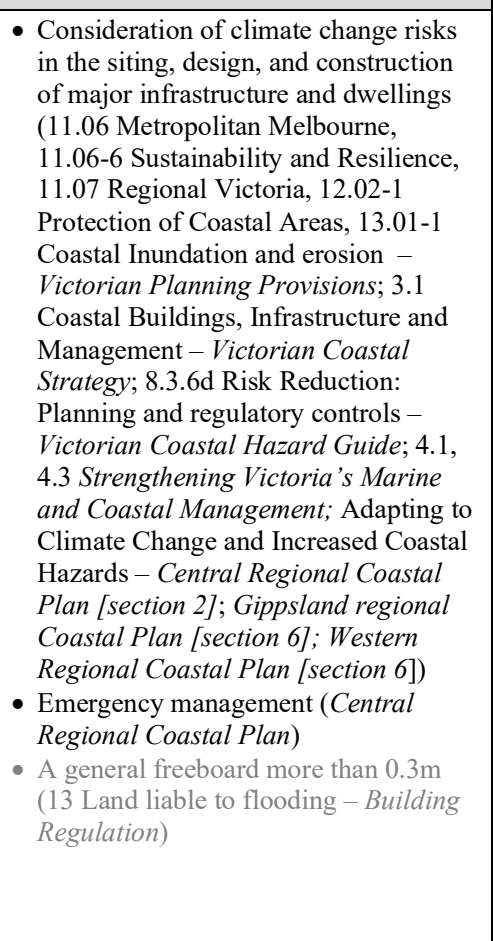 & 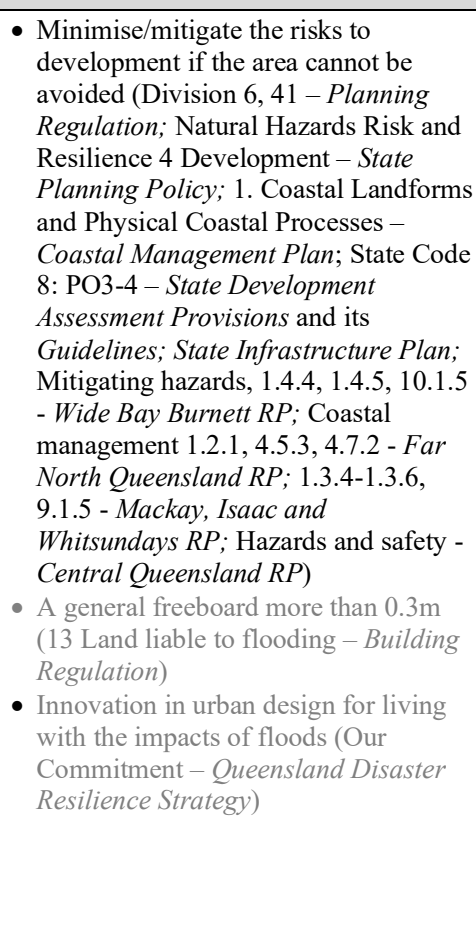 & 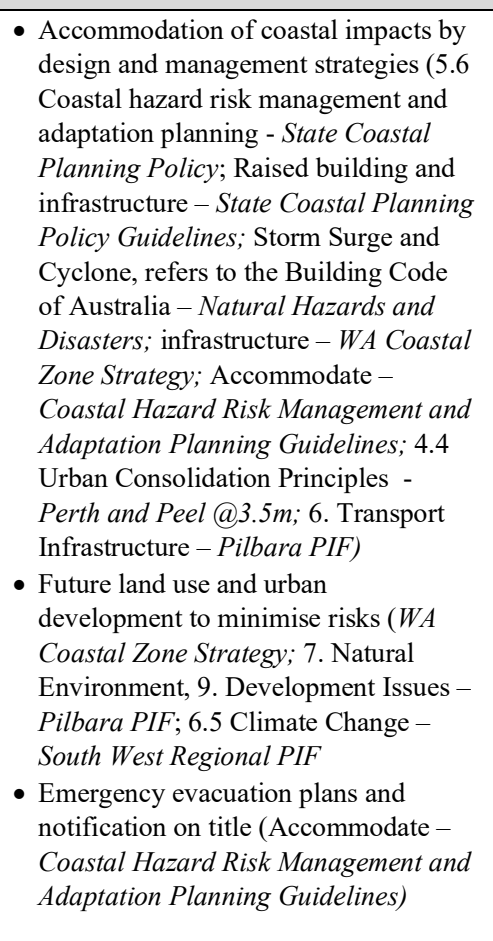 & 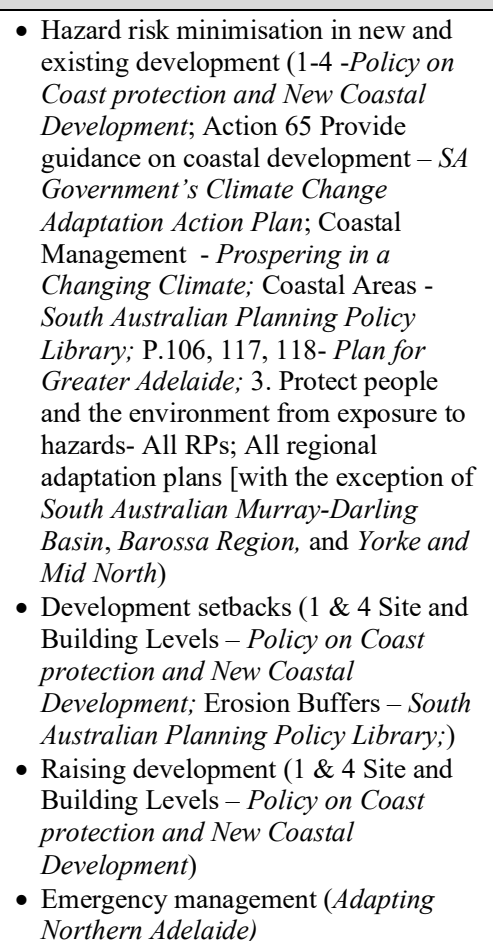 & 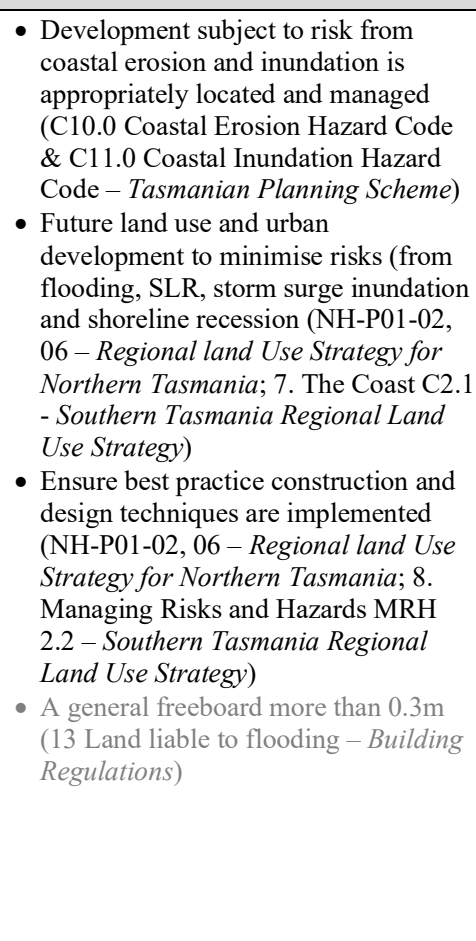 & 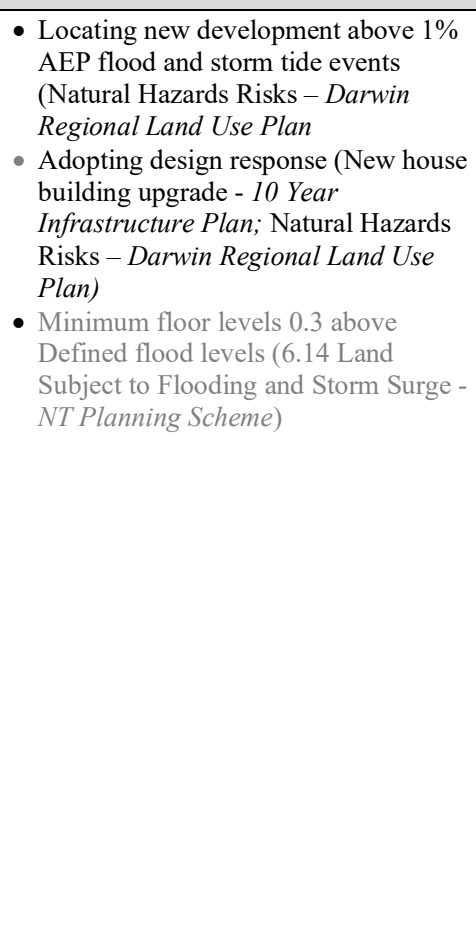 \\
\hline & $\begin{array}{l}\text { - Landward migration of wetlands } \\
\text { (Direction } 3 \text { Manage Natural Hazards } \\
\text { and Climate Change - North Coast } \\
R P \text { ) }\end{array}$ & 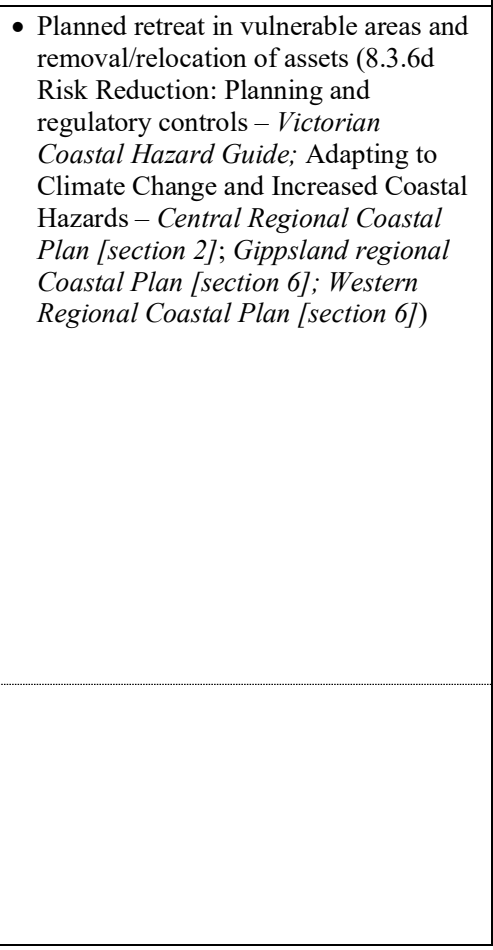 & 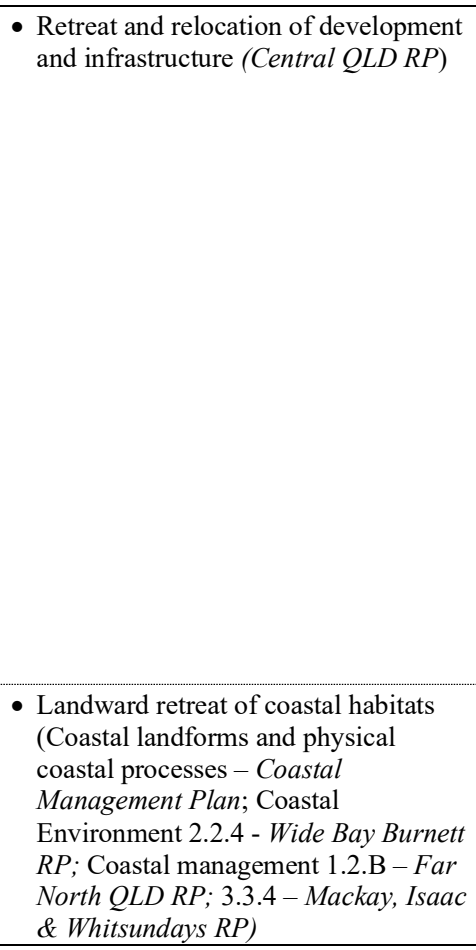 & 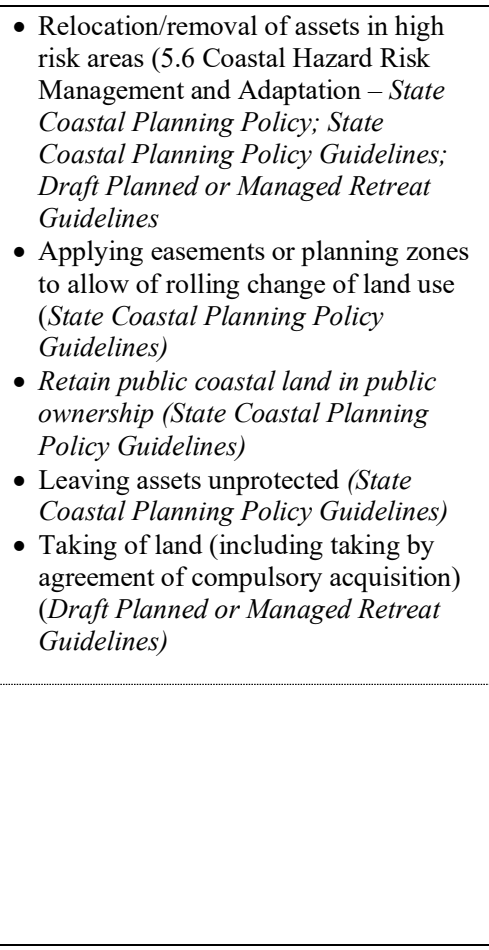 & 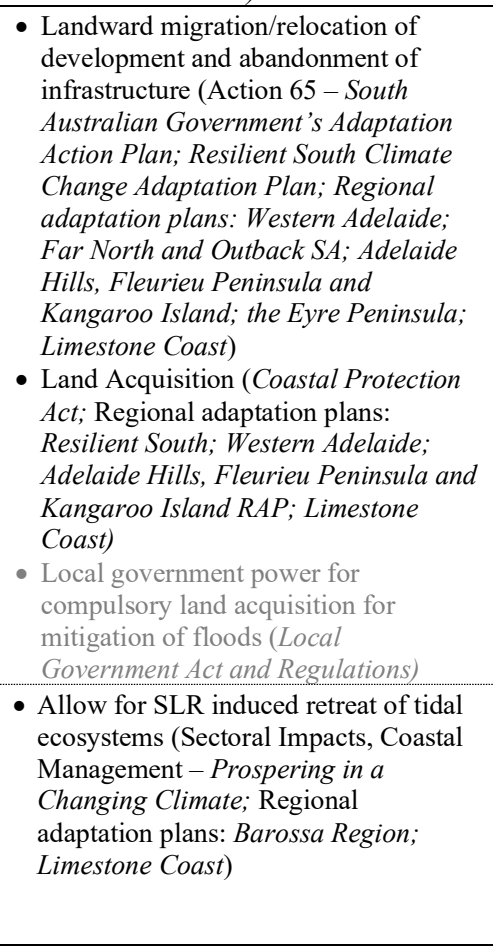 & $\begin{array}{l}\text { - Retraction of existing settlement } \\
\text { locations and relocation of } \\
\text { infrastructure (Living on the Coast- } \\
\text { The Cradle Coastal Regional Land } \\
\text { Use Planning) }\end{array}$ & \\
\hline
\end{tabular}




\begin{tabular}{|c|c|c|c|c|c|c|c|}
\hline & New South Wales & Victoria & Queensland & Western Australia & South Australia & Tasmania & Northern Territory \\
\hline 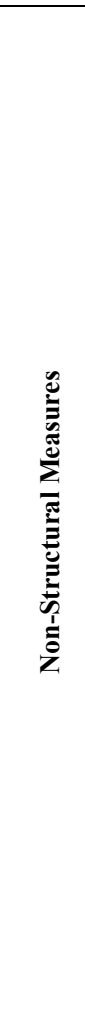 & $\begin{array}{l}\text { - Development of Coastal Zone } \\
\text { Emergency Subplan and Coastal } \\
\text { Management Manual (Part 3, Division } \\
2 \text { \& Coastal Management Programs } \\
\text { and Coastal Management Manual - } \\
\text { Coastal Management Plan) } \\
\text { - Establishment of NSW Coastal } \\
\text { Council (Part } 4 \text { NSW Coastal Council } \\
\text { - Coastal Management Plan) } \\
\text { - Hazard mapping } \\
\text { - Identifying roles and responsibilities } \\
\text { - Research } \\
\text { - Education and training } \\
\text { - Emergency management }\end{array}$ & 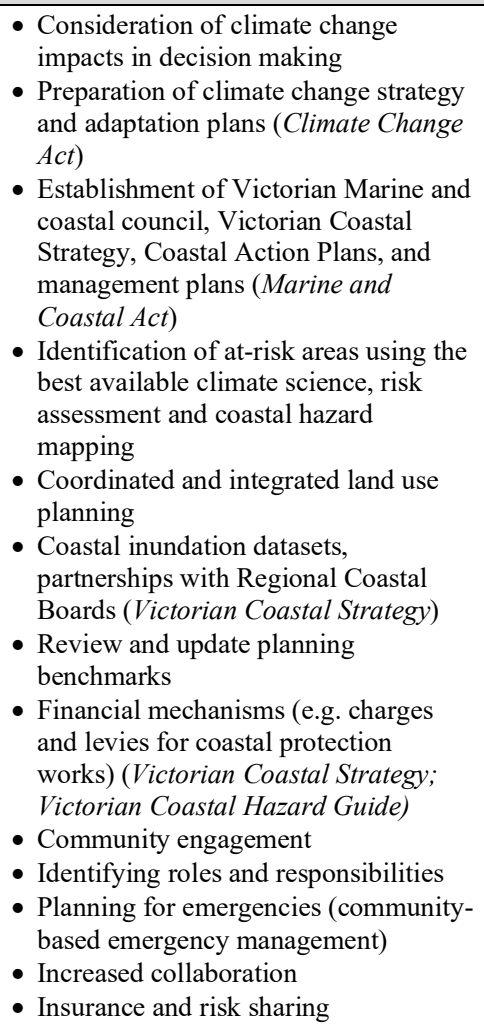 & 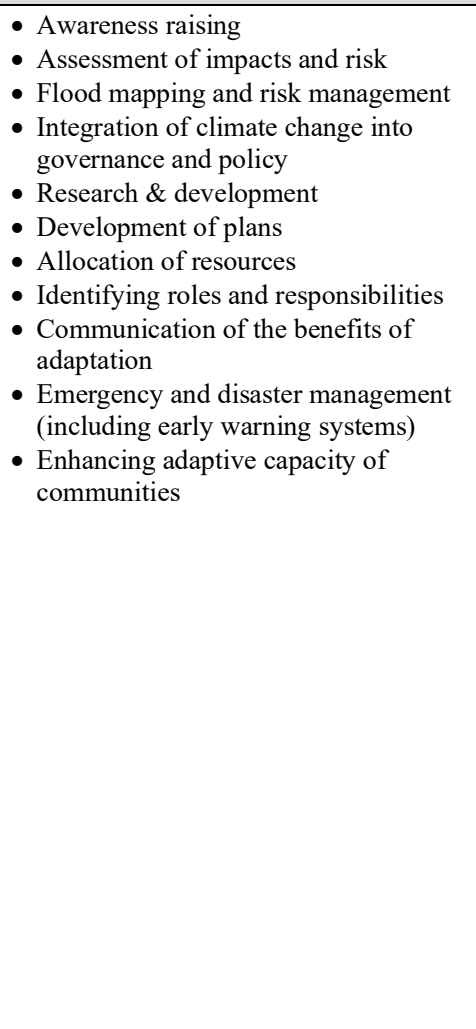 & $\begin{array}{l}\text { - Emergency management } \\
\text { Identification of roles and } \\
\text { responsibilities } \\
\text { Hazard mapping and modelling } \\
\text { Risk management } \\
\text { - Community engagement } \\
\text { Coastal adaptation and protection grant } \\
\text { scheme for coastal monitoring and } \\
\text { data collection (State Coastal } \\
\text { Planning Policy Guidelines) } \\
\text { - Ensuring funding based on coast } \\
\text { benefit analysis (WA Coastal Zone } \\
\text { Strategy) } \\
\text { - Raising awareness }\end{array}$ & 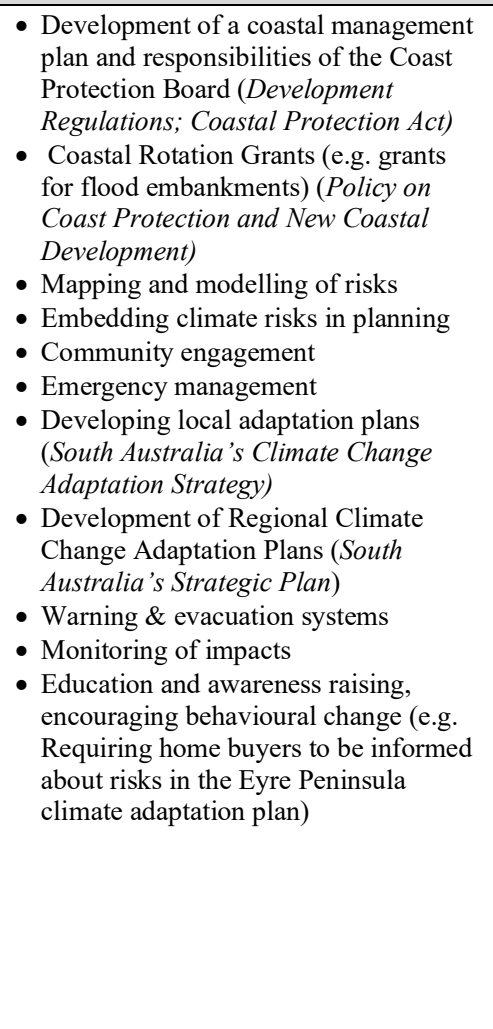 & $\begin{array}{l}\text { - Awareness raising (including online } \\
\text { information) } \\
\text { - Public participation } \\
\text { - Hazard and inundation mapping and } \\
\text { overlays } \\
\text { - Early warning and alerts } \\
\text { - Integration of climate change into } \\
\text { governance and decision making } \\
\text { - Coastal hazard management } \\
\text { - Identification of management } \\
\text { authorities }\end{array}$ & $\begin{array}{l}\text { - Emergency management } \\
\text { Warning and forecasting } \\
\text { Identifying roles and responsibilities } \\
\text { - Hazard Mapping (Darwin Regional } \\
\text { Land Use Plan) }\end{array}$ \\
\hline
\end{tabular}

